\title{
Discovering the Role of the Firm: The Separation Criterion and Corporate Law
}

\author{
Daniel F. Spulber ${ }^{\dagger}$
}

\begin{abstract}
Professor Daniel F. Spulber presents a theory of the firm based on the ability to separate the objectives of the firm from those of its owners. He introduces a separation criterion that defines a firm as a transaction institution such that the consumption objectives of the institution's owners can be separated from the objectives of the institution itself. The separation criterion provides a bright line distinction between firms and other types of transaction institutions. Firms under this criterion include profit-maximizing sole proprietorships, corporations, and limited-liability partnerships. Institutions that are not classified as firms include contracts, clubs, workers' cooperatives, buyers' cooperatives, merchants associations, basic partnerships, government enterprises, and government-sponsored enterprises. The separation theory of the firm yields insights into corporate law that extend and complement the standard contractarian approach. The separation theory of the firm places emphasis on shareholder property rights and corporate governance.
\end{abstract}

\footnotetext{
${ }^{\dagger}$ Elinor Hobbs Distinguished Professor of International Business, Professor of Management Strategy, Kellogg School of Management, Northwestern University, 606 Jacobs Center, 2001 Sheridan Road, Evanston, IL 60208-2013, e-mail: jems@kellogg.northwestern.edu. I am grateful for the support of a grant from the Ewing Marion Kauffmann Foundation for research on entrepreneurship. I thank Michael Baye, Henry Butler, Shane Greenstein, David Haddock, Gillian Hadfield, Peter G. Klein, Jin Li, Henry Manne, Scott Masten, Troy Paredes, Jens Prüfer, Steve Ramirez, Larry Ribstein, John Rust, Scott Stern, and Joshua Wright for helpful comments on an earlier draft.
} 
Discovering the Role of the Firm

TABLE OF CONTENTS

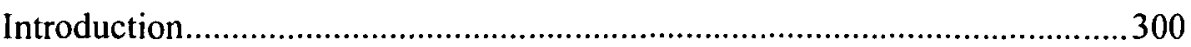

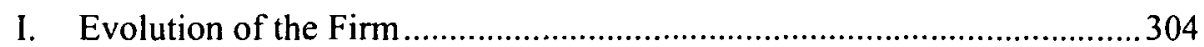

II. The Definition of the Firm and the Separation Criterion ........................307

A. Conditions for Separation ..................................................308

B. Institutions That Are Not Firms ..............................................311

C. Separation Implies that the Firm's Objective is Profit

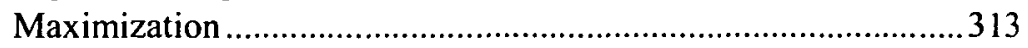

D. Separation of Objectives Allows the Separation of Ownership

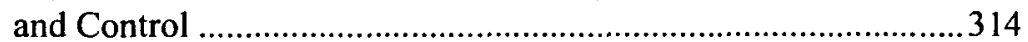

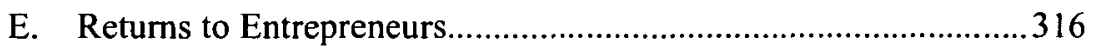

F. The Firm Intermediates Transactions .........................................316

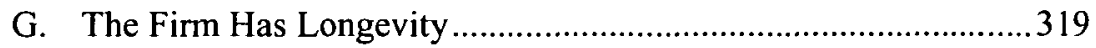

II. The Firm Offers Identity and Anonymity ...............................320

1. The Firm Realizes Economies of Scale from Specialization

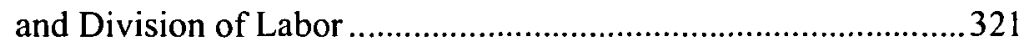

III. Implications of the Separation Theory of the Firm for Corporate Law ....322

A. Property Rights ................................................................... 323

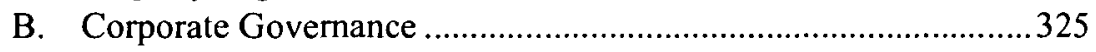

C. The Market for Corporate Control .............................................327

IV. Comparison With Alternative Definitions of the Firm ...........................331

A. The Neoclassical and Industrial Organization Theories of the

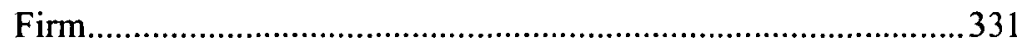

B. The Transaction Cost Theory of the Firm..................................333

C. The Contractual Theory of the Firm ............................................336

D. The Separation Theory of the Firm.............................................338

1. Markets and the Separation Theory of the Firm ......................339

2. Organizations and the Separation Theory of the Firm ............ 343

V. Conclusion .346 


\section{Discovering the Role of the Firm: The Separation Criterion and Corporate Law}

\section{INTRODUCTION}

Defining the role of the firm lies at the heart of many of the most important contemporary public policy debates. These debates can go adrift if they are not anchored by a generally accepted definition of what a firm is. Diverse views of the firm affect antitrust enforcement and regulation of firms throughout the economy, including the energy, banking, transportation, telecommunications, and information technology industries. Determining the properties of firms is central to debates over the desirability of government privatization or nationalization, including the government takeover of Freddie Mac and Fannie Mae.' Discerning the rights and responsibilities of corporations is fundamental to understanding corporate regulation by the Securities and Exchange Commission. ${ }^{2}$ Corporate governance issues arise in statutes such as the Sarbanes-Oxley Act, which was passed in response to recurrent crises of corporate governance such as the demise of Enron and WorldCom, then the largest bankruptcy in United States history. Posing challenges to corporate law, the subprime-mortgage crisis set new records in corporate bankruptcies, including the demise of the global financial services firm Lehman Brothers. The purpose of this Article is to present an economic theory of the firm that serves as an effective guide for public policy and yields insights into corporate law.

The economic contributions of firms are manifest. Firms are responsible for most of the economy's gross domestic product (GDP), employment, innovation, international trade, and economic growth. The U.S. Census counts over 20 million firms, 5 million of which have paid employees, with a total employment of over 100 million people. ${ }^{3}$ There are millions more firms in other developed economies and a growing number of firms in developing countries. ${ }^{4}$ There are over 82,000 multinational corporations worldwide that

1. Freddie Mac is the nickname of the Federal Home Mortgage Corporation and Fannie Mae is the nickname of The Federal National Mortgage Association.

2. See Paul W. Macavoy \& Ira M. Millstein, The Recurrent Crisis in Corporate GOVERNANCE (Palgrave Macmillan 2004).

3. The 1997 U.S. Census lists 5,295,152 firms with paid employees, having a combined sales revenue of $\$ 17.9$ trillion and counts $20,821,935$ firms overall, with sales receipts of over $\$ 18.5$ trillion. U.S. Census Bureau, 1997 Economic Census Minority- and Women-Owned Businesses, http://www.census.gov/epcd/mwb97/us/us.html (last visited Mar. 16, 2009).

4. On cross-country studies of firms in the developed economies, see Stefano Scarpetta et al., The Role of Policy and Institutions for Productivity and Firm Dynamics: Evidence From Micro and Industry Data (Org. for Econ. Cooperation and Dev., Working Paper No. 329, 2002), and Eric J. Bartelsman \& Mark E. Doms, Understanding Productivity: Lessons from Longitudinal Microdata, 38 J. ECON. 
operate across national boundaries with 810,000 foreign affiliates. ${ }^{5}$

But what is a firm? The economic definitions of the firm although highly valuable are fragmented and inconsistent, which can limit guidance for law and public policy. ${ }^{6}$ There is no consensus regarding what firms contribute to the economy. This Article proposes a general unifying framework that can be applied to identify the firm's economic role. ${ }^{7}$ The Article examines how separation of the firm's objectives from those of its owners provides the firm with capabilities that enhance the efficiency of transactions. The Article presents the separation theory of the firm and explores its implications for corporate law.

The theory of the firm presented here provides a means of evaluating and analyzing the variety of existing economic analyses of the firm. The proposed

LITLKATURE 569 (2000). On firms in developing economies, see James R. Tybout, Manufacturing Firms in Developing Countries: How Well Do They Do, and Why?, 38 J. ECON. LiTERATURE 11 (2000).

5. United Nations Conference on Trade and Development, UNCTAD World Investment Report 2009: Transnational Corporations, Agricultural Production and Development (Geneva, 2009).

6. The main economic definitions of the firm can be briefly summarized as follows. The neoclassical economics conception of the firm is that of a producer that owns and operates a production technology. See, e.g., KenNeTH J. ARrow \& F. H. HAHN, General Competitive ANAlysis (HoldenDay 1971). The industrial organization conception of the firm also views the firm as a production technology, often characterized by economies of scale, but also characterizes the firm as a strategic player. The transactions cost economics conception of the firm, which is the most important precursor of our analysis, is based on the work of Ronald Coase who emphasizes that the boundaries of the firm are determined by the transaction costs of using the market in comparison with the firm's internal costs. See Ronald H. Coase, The Nature of the Firm, 4 ECONOMICA 386, 390-405 (1937) (hereinafter "Coase, 1937"); Ronald H. Coase, The Nature of the Firm: Origin, Meaning, Influence, reprinted in THE NATURE OF THE FIRM: ORIGIN, MEANING, INFLUENCE 34-74 (Oliver E. Williamson and Sidney G. Winter, eds., Oxford University Press 1991) (1988) (hereinafter "Coase, 1988"); Ronald H. Coase, The Institutional Structure of Production, 1991 Alfred Nobel Memorial Prize Lecture in Economic Sciences, reprinted in RONALD H. COASE, ESSAYS ON ECONOMICS AND ECONOMISTS 3-14 (University of Chicago Press 1994) (hereinafter "Coase, 1994"). Oliver Williamson builds on Coase's contrast between markets and the firm's internal allocation, but narrows the specification of transaction costs to the concept of "opportunism," commonly referred to as contractual hold-up. See OLIVER E. WILLIAMSON, MARKETS and Hierarchies (Free Press 1975); Oliver E. Williamson, The ECONOMIC INSTITUTIONS OF CAPITALISM (Free Press 1985). Oliver Hart and John Moore, building on Williamson, offer a property rights theory of the firm, in which the purpose of the firm is to combine assets by ownership so as to improve coordination. Oliver D. Hart \& John Moore, Property Rights and the Nature of the Firm, $98 \mathrm{~J}$. POL. ECON. 1119 (1990). The contractual theory of the firm emphasizes the importance of the firm in providing contractual incentives, monitoring, and coordination for its employees primarily to alleviate moral hazard. See Frank H. KNIGHT, RISK, UnCERTAINTY AND Profit (University of Chicago Press 1971) (1921); Armen A. Alchian \& Harold Demsetz, Production, Information Costs, and Economic Organization, 62 AMER. ECON. REV. 777 (1972); Bengt Holmström, The Firm as a Subeconomy, 15 J.L. ECON. \& ORG. 74 (1999). Michael Jensen and Jensen and Meckling provide a theory of the firm as a "nexus of contracts" that serves to allocate risk efficiently. See MICHAEL C. JENSEN, A THEORY OF THE FIRM (Harvard University Press 2000); Michael C. Jensen \& William H. Meckling, Theory of the Firm: Managerial Behavior, Agency Costs and Ownership Structure, 3 J. FIN. ECON. 305 (1976). These more specialized views of the firm are consistent with the general definition presented here. The differences and similarities are explored in a later section of the Article.

7. This discussion draws upon the analyses presented in DANIEL F. SPULBER, THE THEORY OF THE Firm: MICROECONOMICS WITH ENDOGENOUS ENTREPRENEURS, FIRMS, MARKETS, AND ORGANIZATIONS (Cambridge University Press 2009) (hereinafter "SPULBER, MICROECONOMICS"), and DANiEl F. SPUlber, MARKET MiCROSTRUCTURE: INTERMEDIARIES AND THE THEORY OF THE FIRM (Cambridge University Press 1999) (hereinafter "SPULBER, MARKET MICROSTRUCTURE"). 
formal definition of the firm should prove valuable in understanding how the firm functions within the context of social, legal, and political constraints. ${ }^{8}$ The firm as an institution is related to social conventions such as language, norms, rules, customs, and kinship. ${ }^{9}$ The firm is defined by legal concepts such as those regulating property, contracts, business transactions, organizations, financial markets, and corporate governance. The firm operates within a political framework as well, as it is subject to taxation, regulation, and ownership restrictions. The definition of the firm must be sufficiently precise so that it distinguishes the firm from other types of institutions.

To provide a meaningful definition of the firm, it is necessary to establish a bright line distinction between the firm and direct exchange among consumers. To identify the difference between the firm and direct exchange, I introduce the separation criterion. An institution satisfies the separation criterion if the objectives of the institution can be distinguished from the consumption objectives of its owners. The separation criterion substantially extends the discussion of separation introduced by Irving Fisher. ${ }^{10}$ The Fisher Separation Theorem is essential to the foundations of neoclassical economics and finance. Fisher showed that the neoclassical firm's investment decisions could be separated from the owners' consumption and savings objectives. ${ }^{11}$ Fisher's classic result takes as a given the neoclassical definition of the firm as a production technology. The separation criterion that is presented in this Article substantially extends this approach by establishing a standard for evaluating practically any type of economic institution. The separation criterion asks whether or not the objectives of an economic institution can be separated from the consumption objectives of its owners.

The critical difference between firms and direct exchange is the separation of the firm's objectives from those of its consumer-owners. This provides the

8. The word "firm" derives from the Latin word "firmare" referring to a signature that confirmed an agreement by designating the name of the business. The institution of the firm has properties that extend beyond its formation and identity.

9. According to John R. Commons, "Transactions are the means, under operation of law and custom, of acquiring and alienating legal control of commodities, or legal control of the labor and management that will produce and deliver or exchange the commodities and services, forward to the ultimate consumers." John R. Commons, Institutional Economics, 21 AMER. ECON. REV. 648 (1931). Karl Polanyi argued that "man's economy, as a rule, is submerged in his social relationships," through reciprocity, redistribution and the household. KARL POLANYI, THE GREAT TRANSFORMation: THE POLITICAL AND ECONOMIC ORIGINS OF OUR TIME 44 (Beacon Press 2001) (1944). Ian R. Macneil argues that "Contract without the common needs and tastes created by society is inconceivable; contract between totally isolated, utility-maximizing individuals is not contract, but war; contract without language is impossible; and contract without social structure and stability is-quite literally-rationally unthinkable. The fundamental root, the base, of contract is society." IAN R. MACNEIL, THE NEW SOCIAL CONTRACT: AN INQUIRY INTO MODERN CONTRACTUAL RELATIONS (Yale University Press 1980).

10. See IRVing Fisher, The NATURE OF CAPITAL AND INCOME (Macmillan 1906); IRVING Fisher, RATE OF INTEREST: ITS NATURE, DETERMINATION AND RELATION TO ECONOMIC PHENOMENA (Macmillan 1907); IRVING FISHER, THE THEORY OF INTEREST: AS DETERMINED BY IMPATIENCE TO SPEND INCOME AND OPPORTUNITY TO INVEST IT (Macmillan 1930).

11. See IRVING FISHER (1906, 1907, 1930), supra note 10. 
basis for a formal definition: A firm is a transaction institution whose objectives can be separated from those of its owners. Corporations are firms because their objectives are distinct from those of their shareholders who are only concerned with their residual returns. Sole proprietorships and whollyowned enterprises are firms when they operate with objectives that are separate from the consumption objectives of their owners. Entrepreneurial startups often are not firms because their objectives are intertwined with those of the entrepreneur. Therefore, firms can take many forms including corporations, close corporations, sole proprietorships, and limited-liability partnerships (LLCs), This is a question of the economic functions of the institution rather than the many legal labels that describe business enterprises.

Having defined the firm, a key step is to perform a conceptual experiment that considers the economy without firms. Then, the economy is composed solely of individuals, also referred to as "consumers." In the absence of firms, consumers can engage in direct exchange through a variety of transactions, including bartering, spot transactions with fiat money, and contracts. In addition, through direct exchange, individuals can form many types of "consumer organizations" that are not firms, including clubs, consumers' cooperatives, workers' cooperatives, nonprofits, merchants' associations, and basic partnerships. Direct exchange between consumers does not satisfy the separation criterion. Most types of consumer organizations have objectives that cannot be separated from those of their owners so that they are not firms. Direct exchange between consumers is the benchmark for evaluating the economic contribution of the firm. The firm plays an economic role if it can improve the efficiency of transactions by intermediating exchange between individuals.

Separation is the basis for the firm's contribution to the economy because it allows the firm to improve economic efficiency in comparison with direct exchange between consumers. When there is a separation of objectives, the firm's owners unanimously prefer that the firm pursue the objective of profit maximization. The firm's owners pursue their consumption objectives of maximizing utility subject to their budget constraints. The only connection between the objectives of the firm and those of its owners is the income generated by the firm's profits. By inducing profit maximization, separation helps firms choose efficient employment levels and provide incentives for its employees. Intermediated exchange through firms improves upon direct exchange as a result of the separation of objectives. Separation allows the firm to serve as a profit-maximizing intermediary in economic transactions.

The separation theory of the firm yields insights into corporate law that extend and complement the standard contractarian approach. The separation theory of the firm places emphasis on shareholder property rights and corporate governance. With separation, ownership of firms represents financial assets that facilitate divestiture, acquisition, and mergers. The ability to trade ownership of 
firms as financial assets provides liquidity to investors and allows for market valuation of the firm, thus helping firms to raise capital. Separation is the basis of the market for corporate control, which provides incentives for managers.

The article is organized as follows. Section I examines the development of the firm. Section II introduces the separation criterion and defines the firm. Section III explores the implications for corporate law of the separation theory of the firm. Section IV compares the separation theory of the firm with the major economic theories of the firm. Section $V$ concludes the discussion.

\section{EVOLUTION OF THE FIRM}

The firm is a relatively recent institution, taking recognizable form within the last two-hundred years. Farmers, artisans, and merchants from the earliest times to the eighteenth century operated enterprises that are precursors to the contemporary firm. ${ }^{12}$ Merchant houses established enterprises to finance and manage ventures necessary to conduct trade. ${ }^{13}$ Other institutions that presage the contemporary firm include families, feudal estates, religious organizations, merchant associations, armies, and government bureaucracies. ${ }^{14}$

What distinguishes traditional farmers, artisans, and merchants from firms is that their enterprises tended to be integrated with the owners' personal affairs. There was minimal if any separation between the owners' commercial activities and their consumption activities. Most merchants operated as family businesses, so that the merchant family was closely tied to the firm: "the business being in the family and the family being in the business." 15 The activities of merchants became increasingly sophisticated, reaching a high level during the commercial revolution in Europe during the first half of the Middle

12. The linguistic connection between merchants, markets and commerce is long established. The words "merchant" and "market" have the same Latin origins. Merchant comes from the word mercari, which means to trade, and market comes from mercatus which is the past participle of mercari. The word "mercari" itself derives from the Latin word merx, meaning wares, merchandise, or goods for trade. The word "commerce" also derives from commercium, which is bringing together goods for trade. WEBSTER's NEW WORLD DiCTIONARY OF THE AMERICAN LANGUAGE (2d College ed. 1976).

13. Karl Moore and David Lewis examine the forerunners of the international business firm in four ancient empires that together span two millennia. KARL MOORE \& DAVID LEWIS, BIRTH OF THE Multinational (Copenhagen Business School Press 1999).

14. See Yoram Ben-Porath, The F-Connection: Families, Friends, and Firms and the Organization of Exchange, 6 POPULATION \& DEv. REV. 1 (1980) (on families); ROBERT B. EKELUND, JR. ET AL., SaCred Trust: The Medieval ChuRCh as AN ECONOMIC FIRM, (Oxford University Press 1996) (on religious organizations); Avner Greif, Reputation and Coalitions in Medieval Trade: Evidence on the Maghribi Traders, 49 J. ECON. HIST. 857 (1989) (on merchant associations); Avner Greif, Contract Enforceability and Economic Institutions in Early Trade: The Maghribi Traders' Coalition, 83 AMER. ECON. REV. 525 (1993) (same); MAX WEBER, ECONOMY AND SOCIETY 982 (Guenther Roth et al. eds., Bedminster Press 1968) (on armies); JOSEPH A. SCHUMPETER, THE THEORY OF ECONOMIC DEVELOPMENT 163-64 (Transaction Publishers 1997) (on govemment bureaucracies).

15. Robert L. Reynolds, Origins of Modern Business Enterprise: Medieval ltaly, 12 J. ECON. HIST. 350 (1952). 
Ages. $^{16}$ Merchants' capabilities continued to develop from the fourteenth century to the end of the eighteenth century. Alfred D. Chandler observes that: "In the 1790s American businessmen still relied entirely on commercial practices and procedures invented and perfected centuries earlier by British, Dutch, and Italian merchants."17

The contemporary firm takes a more recognizable shape during the nineteenth century. The Industrial Revolution led to the creation of large manufacturing and distribution enterprises starting in the late eighteenth century. ${ }^{18}$ Chandler points out that those companies seeking to benefit from technological change invested not only in production facilities, but also in distribution and management. ${ }^{19}$ At the same time, companies were established that engaged in large-scale retail and wholesale distribution. Merchants began to specialize in one or two types of goods, "concentrating more and more on a single function: retailing, wholesaling, importing, or exporting" over the fifty years after the i790s. ${ }^{20}$ According to Chandler:

In the 1850 s and 1860 s the modern commodity dealer who purchased directly from the farmer and sold directly to the processor took over the marketing and distribution of agricultural products. In the same years, the full-line, full-service wholesaler began to market most standardized consumer goods. In the $1870 \mathrm{~s}$ and 1880 s the modern mass retailer - the department store, the mail order house, and the chain store - started to make inroads on the wholesaler's markets. ${ }^{21}$

These mass-marketing enterprises employed extensive administrative coordination, reduced the number of total transactions, increased the speed and regularity of the flow of goods, and took advantage of the railroads, the telegraph, the steamship, and improved postal services. ${ }^{22}$

According to Chandler: "managers of large American railroads during the $1850 \mathrm{~s}$ and $1860 \mathrm{~s}$ invented nearly all of the basic techniques of modern accounting," including financial, capital, and cost accounting. ${ }^{23}$ After 1900, the growth of mass production brought with it the development of modern factory cost accounting. ${ }^{24}$ Advanced management techniques developed at large diversified firms such as General Electric, Du Pont, and General Motors were

16. Joseph Gies and Frances Gies refer to the development of merchants and finance in Europe between 1000 and 1500 as "the commercial revolution." JOSEPH GIES \& FRANCES GIES, MERCHANTS AND MONEYMEN: THE COMMERCIAL Revolution, 1000-1500 (Crowell 1972). The term also appears in POLANYI, supra note 9.

17. See generally Alfred D. Chandler, JR., The Visible HAND: The MANagerial Revolution IN AMERICAN BUSINESS (Harvard University Press 1977).

18. Id.

19. See generally Alfred D. Chandler, JR., SCALE AND SCOPE: THE DYNAMICS OF INDUSTRIAL CAPITALISM (Harvard University Press 1990).

20. CHANDLER, supra note 17 , at 15 .

21. Id. at 209.

22. See generally id.

23. Id. at 109.

24. Id. at 278 . 
widely adopted during the $1920 \mathrm{~s}$, particularly the multidivisional organization structure and accounting, budgeting, and forecasting methods. ${ }^{25}$

Legal developments accompanied changes in the technology and functions of enterprises. Margaret M. Blair points out that "[i]n 1800, there were only 335 chartered business corporations in the U.S.," most chartered after $1790 .^{26}$ However, by 1890 , the U.S. led the world with almost 50,000 chartered business corporations. ${ }^{27}$ Unincorporated joint stock companies, which evolved out of partnership law, died out, while businesses increasingly switched to the corporate form. Blair argues that unincorporated joint stock companies could be easily broken up by the partners or their heirs seeking to remove their capital from the firm. ${ }^{28}$ Corporations became the dominant legal form because courts recognized them as "separate legal entities with potentially unlimited life," whose assets would be protected from owners who could then sell their shares to others based on the market value of the company. ${ }^{29}$

Hillman observes that: "there seems to be little practical distinction between corporations and partnerships when either form of firm is populated by a large number of shareholders or partners, as the case may be."30 Ribstein points out that partnerships already had developed continuity and other entity features by the early nineteenth century so that the ability to lock in capital need not distinguish between organizational forms. ${ }^{31}$ Although there are many large corporations, partnerships with hundreds or even thousands of owners such as major accounting firms are rare. They tend to concentrate in service industries, particularly law, accounting, management consulting, and medicine. Such large partnerships are characterized by centralized management and an organizational hierarchy in which the status and authority of individual partners

25. See id. at 464; Peter F. Drucker, Concept of the Corporation (Revised ed., John Day Co. 1972) (1946).

26. See Margaret M. Blair, Why Markets Chose the Corporate Form: Entity Status and the Separation of Asset Ownership from Control (Georgetown Univ. Law Ctr., Bus., Econ. and Regulatory Policy Working Paper No. 429300, 2003). See also JOSEPH S. DAVIS, ESSAYS IN THE EARLIER HISTORY OF AMERICAN CORPORATIONS (Russell \& Russell 1965) (1917).

27. Blair, Corporate Form, supra note 26, at 5 (citing DOW VOTAW, MODERN CORPORATIONS (Prentice Hall 1965) and RoBERT E. WRIGHT, THE WEALTH OF NATIONS REDISCOVERED: INTEGRATION AND EXPANSION IN AMERICAN FINANCIAL MARKETS, 1780-1850 (Cambridge University Press 2002)).

28. Blair, Corporate Form, supra note 26, at 3.

29. Id. at 4 .

30. See Robert W. Hillman, The Bargain in the Firm: Partnership Law, Corporate Law, and Private Ordering within Closely-Held Business Associations (Univ. of Cal., Davis Sch. of Law, Research Paper No. 37, 2005).

31. See Larry E. Ribstein, Should History Lock In Lock-In?, 41 TULSA L. REV. 525 (2006). Ribstein notes that in contrast to corporations, partnerships let members transfer economic interests in the firm but not necessarily control rights. See Larry E. Ribstein, Why Corporations?, I BERKELEY BUS. L.J. 183, 189 (2004). Ribstein also states that any member of the partnership has the power to dissolve a partnership or to seek to be bought out by the partnership. Id. Ribstein argues that liquidation does not explain the switch to corporations because partners can prevent liquidation through the partnership agreement and the partners can contract for buyout rights. Ribstein, Should History Lock In Lock-In, at 526. 
varies considerably. ${ }^{32}$

The common law viewed a partnership as the aggregate of its members. ${ }^{33}$ In a classic treatise, Justice Nathaniel Lindley wrote that: "merchants and lawyers have different notions respecting the nature of a firm." ${ }^{34}$ Lindley observes that "Commercial men and accountants are apt to look upon a firm in the light in which lawyers look upon a corporation, i.e., as a body distinct from the members composing it, and having rights and obligations distinct from those of its members." 35 Lindley points out that for lawyers, in contrast, "Partners are called collectively a firm."36

To end the "hopeless confusion in law and practice," 37 the Uniform Partnership Act (UPA) of 1914 attempted to take a middle position, treating a partnership as a collective for some purposes and as a separate entity for other purposes. ${ }^{38}$ The Revised Uniform Partnership Act of 1997 moves toward the corporate law view of the partnership - an institution whose objectives are distinct from those of its owners-stating that, "A partnership is an entity.",39

\section{THE DEFINITION OF THE FIRM AND THE SEPARATION CRITERION}

This section introduces a general theory of the firm. The definition is built on a specific test for determining whether or not an economic institution is a firm, which I refer to as the separation criterion. An institution satisfies the separation criterion when its objectives are separate from the consumption objectives of its owners. A firm is a transaction institution that satisfies the separation criterion.

The separation criterion provides an economic definition of the firm. This definition transcends the many legal labels used to describe businesses, including for example, corporations, sole proprietorships, close corporations, LLPs, and LLCs. Separation refers to the distinction between the objectives of the institution and the consumption objections of the individuals who are its owners. Separation occurs when the institution's owners operate the firm to maximize the firm's profits, that is, when they are only affected by the income

32. See Hillman, supra note 30.

33. See Nathaniel L. Lindley, a Treatise on the Law of Partnership $\left(5^{\text {th }}\right.$ ed., C. H. Edison 1888). Lindley is also quoted in FLOYD R. MECHEM, ELEMENTS OF THE LAW OF PARTNERSHIP (Callaghan \& Co. 1896).

34. See Lindley, supra note 33 , at 110.

35. Id.

36. Id.

37. See William D. Lewis, The Uniform Partnership Act, 24 YALE L.J. 617, 629 (1915), quoted in Gary S. Rosin, The Entity-Aggregate Dispute: Conceptualism and Functionalism in Partnership Law, 42 ARK. L. REV. 395, 399 (1989).

38. Rosin approvingly calls this a functional approach and argues for rejecting the "legal-person fiction" as well as the concept of the aggregate. Rosin, supra note 37.

39. UNIF. PARTNERSHIP ACT $\$ 201,6$ U.L.A. 79 (revised 1997). See Hillman, supra note 30, for further discussion. 
generated by the firm. Separation does not occur when the institution's owners use the institution to generate specific personal benefits for its owners such as consumption of goods and services, perks, employment, social interaction, individual goals, and transactions with other owners.

The definition of a firm does not depend on whether or not ownership is concentrated. A family farm or a closely-held business that maximizes its earnings is a firm. A family farm or a closely-held business whose objectives include providing consumption goods and services to its owners is not a firm. A partnership is a firm when it maximizes earnings; it is not a firm when it maximizes the average benefits of its members who provide skills, effort, investment, and other resources to the partnership.

The separation criterion provides a bright line distinction between firms and consumer organizations. The objectives of many types of organizations; such as clubs, groups of contracting individuals, buyers' cooperatives, workers' cooperatives, nonprofits, merchants' associations, and basic partnerships, cannot be distinguished from those of their owners. For example, the objective of a club is to maximize the consumption benefits of its members. This means that clubs choose their level of services, their membership size, and other features to maximize the average benefits of its members who consume the services of the club. This contrasts with a firm that maximizes profits for its owners. The owners of the firm are generally distinct from its customers.

The firm will be economically viable only if it offers efficiencies that are greater than those offered by consumer organizations or contracts between individuals. The firm separates contracts from direct interpersonal relationships by serving as an intermediary, such as a broker or a merchant, or by establishing markets and organizations. Since the firm is defined by the separation criterion, it must be the case that separation provides the firm with enhanced transaction capabilities. The purpose of this section is to show how separation provides the firm with "super powers" that are unavailable either to consumer organizations or to contracts between individual consumers.

\section{A. Conditions for Separation}

The separation criterion extends Fisher's separation theorem to general economic environments. The Fisher separation theorem shows that the firm's optimal investment decisions are independent of the preferences of its owners and independent of how the investment is financed. ${ }^{40}$ The firm's owners are only affected by the firm's decisions through their wealth. They carry out their consumption and saving decisions through product markets and financial

40. See IRVING FISHER (1906, 1907, 1930), supra note 10. 
markets. In contrast, the separation criterion is a way of asking whether an institution's objectives are separable from those of its owners. Fisher's separation theorem fits squarely within the neoclassical tradition because it requires price-taking behavior by both consumer-owners and firms. ${ }^{41}$ In contrast, the separation criterion does not require price-taking behavior. ${ }^{42}$ The Fisher separation theorem assumes that there are no transaction costs and that there exists a complete set of competitive markets. In contrast, the separation criterion allows for the existence of transaction costs and the absence of markets. The Fisher separation theorem applies to neoclassical firms that are fully described by their production technologies. In contrast, the separation criterion can be applied to evaluate almost any type of institution engaged in economic transactions.

The ability of an institution to separate its objectives from those of its owners is closely connected to whether or not there are gains from trade. When individual consumers cannot achieve gains from trade due to transaction costs, they will engage in autarky production, essentially managing production for their consumption benefits. When there are little or no transaction costs and markets exist, consumers achieve gains from trade by decoupling production and consumption decisions. The neoclassical separation theorem is based on two sources of gains from trade. The consumer obtains part of the gains from trade by adjusting consumption and buying and selling goods in markets at given prices. The firm obtains part of the gains from trade by adjusting production and by buying and selling goods in markets at given prices, generating profits that add to the income of its consumer-owners. By entering markets and trading with others, a firm and its owners achieve gains from trade.

Market opportunities to buy and sell goods imply that groups of consumers do not need to rely on operating production to achieve their consumption objectives. Firms can choose the best mix of products based on their technology and consumer demands, and consumers can choose the best mix of goods to buy based on their preferences and endowments. Markets allow the separation of production decisions from consumption decisions. This has additional implications. Market opportunities for consumers and firms to form contracts with other consumers and firms imply that consumers do not need to operate production to transfer resources over time. Also, market opportunities for consumers and firms to share risk with other consumers and firms imply

41. Id.

42. Price-taking behavior is not a necessary condition for separation of objectives. Spulber shows that the separation of objectives still holds when firms engage in monopolistic competition and choose prices. SPULBER, MICROECONOMICS, supra note 7. Because of product differentiation, the effect of the firm's profit on owner's income is substantial while the expenditure effect of the firm's price is negligible. The discussion also generalizes the Fisher separation theorem to price setting firms and shows that with product differentiation, the owners' consumption-saving decisions can be separated from the firm's investment decisions. 
that consumers do not need to operate production to allocate resources under uncertainty.

Consumer organizations generally are not firms because they maximize the consumption benefits of their members. For example, a worker's cooperative maximizes the average benefits of its members. Selling memberships fundamentally transforms the objectives of a worker's cooperative, which then maximizes profit rather than the benefits of its members. ${ }^{43}$ In this way, selling memberships separates the objectives of the worker's cooperative from the consumption objectives of its members and transforms the worker's cooperative into a firm. The original members of the cooperative have an incentive to sell memberships because they obtain returns from the sale. The members of the cooperative obtain benefits from selling memberships to individuals outside the original group of members because doing so generates gains from trade. The introduction of a market for memberships turns the worker's cooperative into a firm.

Separation of objectives helps to achieve gains from trade. The institution can transact with buyers and sellers who are not its owners. The owners of the institution can use their earnings to transact with other market participants. Consumers do not need to operate a club or cooperative to obtain economies of scale or local public goods. Consumers can obtain these benefits through transactions with firms. A firm can achieve economies of scale and can supply local public goods to its customers. The firm's owners obtain benefits because they receive the residual returns generated by the firm.

Property rights are fundamental to the firm because they allow gains from trade. They allow the operation of markets because individuals and institutions can trade goods and services and realize the returns on investments. Property rights allow the owners to sell shares in the firm to outside investors. They provide owners with rights to the firm's returns and rights to control the firm. The firm's owners cannot manage the firm without exercising control rights. The firm's owners will not devote effort to operating and monitoring the firm unless they obtain returns to their efforts. Entrepreneurs will not devote resources to establishing firms unless they will become its owners, and receive returns and rights of control. The firm's has a greater ability to secure capital when it can provide investors with collateral based on the firm as an asset.

Efficient markets require property rights to be complete, exclusive, and transferable. Consumer organizations may fail to satisfy any or all of these requirements. Consumer organizations such as clubs, cooperatives, nonprofits, and associations are owned in common by their members, so that there are not well-defined shares that are owned exclusively. The organization is common

43. Gregory K. Dow, Governing the Firm: Workers' Control in Theory and Practice (Cambridge University Press 2003). 
property rather than being divided into separate shares. In basic partnerships, common ownership poses problems of free riding and moral hazard. Collective ownership in basic partnerships contrasts with corporate shares that can be transferred through capital markets. Transferable ownership shares allow members to realize gains from trade through separation of objectives, giving them incentives to establish a firm.

\section{B. Institutions That Are Not Firms}

The separation criterion provides a clear distinction between firms and other types of transaction institutions. Among consumer organizations that do not satisfy the separation criterion are clubs, workers' cooperatives, buyers' cooperatives, merchants' associations, some types of basic partnerships, some forms of nonprofits, and government enterprises.

Sole proprietorships and closely-held businesses that intermingle the consumption objectives of their owners with the activities of the enterprise generally do not satisfy the separation criterion. For example, traditional family farms that primarily serve the consumption benefits of their owners are not firms. When sole proprietorships, family businesses, closely-held businesses, and limited liability partnerships are managed to maximize the earnings of the business, they become firms. These institutions can be firms even when the owners and managers are the same individuals, as long as the institutions pursue objectives that are distinct from the consumption objectives of their owners.

Many types of transaction institutions do not satisfy the separation criterion. Contracts and other transactions between individuals generally do not satisfy the separation criterion since they reflect the diverse objectives of the parties to the transaction. Clubs are not firms because they seek to maximize the net benefits that their members receive from jointly consuming the services of the club's facilities. Maximizing average benefits yields a different outcome than maximizing total benefits. Basic partnerships are not firms since the partnership's objective is to maximize the individual returns to each of its partners, rather than total returns. For example, in an equal sharing partnership, partners consider the marginal effects of their efforts on their share of total benefits rather than the marginal effects of their efforts on total benefits. Nonprofits are not firms if their objectives cannot be separated from those of their owners, which may include managers, employees, and members. For example, arts organizations provide consumption goods for their members. Some nonprofit institutions can achieve separation of objectives by following their founders' intent although these types of institutions differ from profit- 
maximizing firms. ${ }^{44}$

Enterprises that are established and owned by the government are not firms because the separation criterion is not satisfied. Government-owned enterprises include the Tennessee Valley Authority, the National Railroad Passenger Corporation (Amtrak), and the Federal Deposit Insurance Corporation (FDIC). Companies that come under the control of government through nationalization or financial bailouts, such as General Motors, also cease to act as firms because the separation criterion is not satisfied.

The objectives of government enterprises are those of the government that owns them. These objectives may include influencing voters, taxation, increasing employment, subsidizing consumption, subsidizing production, bearing risk, industrial policy, regional economic development, and transferring wealth among individuals in the society. Government enterprises promote public policy objectives rather than independent objectives because no separation is possible between these institutions' objectives and those of the government. Public oversight, control, subsidies, administrative appointments and other policy instruments, along with an absence or limits on private ownership and control force the institution to pursue public policy objectives. Because such public policy objectives typically conflict with profit maximization, government enterprises often incur significant losses in pursuit of public objectives.

Government-sponsored enterprises (GSEs), such as Fannie Mae and Freddie Mac, also are not firms. These institutions lack a separation of objectives due to various government controls. Although these enterprises were privatized, their congressional charter maintained elements of public ownership. Unlike a private corporation, the government exercised rights of control. In addition, the government provided a line of credit through the Treasury, the president could appoint five members of its board of directors, and the company's debt could serve as collateral for government deposits in private banks. $^{45}$ The companies incurred significant losses and were nationalized by the federal government, converting them from GSEs to public enterprises. $^{46}$

44. Carl Schramm points out that the trustees of a private foundation should follow the "founder's express or imputed intent" free of constituencies and stakeholders, while seeking to "advance human welfare within the context of democratic capitalism." Carl J. Schramm, Law Outside the Market: The Social Utility of the Private Foundation, 30 HARV. J.L. \& PUB. POL'Y 355, $412-13$ (2006).

45. See Peter J. Wallison \& Charles W. Calomiris, The Last Trillion-Dollar Commitment: The Destruction of Fannie Mae and Freddie Mac, FINANCIAL SERVICES OUTLOOK, AEI ONLINE, September $30,2008$.

46. After accounting scandals in 2003 and 2004, Fannie Mae and Freddie Mac increased their pursuit of public policy objectives. As a consequence, the companies incurred substantial losses on more than $\$ 1$ trillion of subprime and Alt-A investments between 2005 and 2007 . Wallison \& Calomiris, supra note 45 . 


\section{Separation Implies that the Firm's Objective is Profit Maximization}

With separation, the firm's owners are affected by the firm's decisions only through the impact of the firm's profit on their income. The firm's owners make consumption decisions by choosing the most-preferred consumption bundle given their income. As a result, the firm's owners unanimously prefer that the firm maximize profits. ${ }^{47}$ Profit maximization by the firm yields decisions that differ from those of consumer organizations. Firms and consumer organizations generally choose different prices, outputs, product quality, investment levels, employment levels, and technologies. The differences in the choices made by firms and by consumer organizations determine the economic impact of firms.

The differences in the decisions of a firm from those of consumer organizations result in greater economic efficiency under some conditions. Generally, consumer organizations are concerned with maximizing average benefits, which often results in inefficient outcomes. Firms consider the marginal benefits of their decisions, which often results in greater economic efficiency. Profits provide incentives for firms to carry out their activities, including price setting. Increased competition between firms limits their market power and can enhance economic efficiency. Firms play an economic role when the combination of profit maximization and competition leads to outcomes that are more efficient than consumer organizations.

As a consequence of the separation of objectives, the firm is an additional player in the economy. Essentially, a firm adds degrees of freedom to a set of economic transactions. If there are $\boldsymbol{n}$ consumers, adding a firm means that there are $n+1$ economic actors, and potentially $n$ additional economic relationships between the consumers and the firm. This fundamentally changes the set of feasible transactions. The firm is an independent decision maker as a result of separation from its owners, employees, and trading partners. Firms are players with different strategic objectives than consumers because firms maximize profits.

The separation criterion implies that the firm is a transferable asset. Suppose that property rights to firms are well defined, so that owners of firms potentially can transfer these rights. The separation of the owners' consumption objectives and the objectives of the firm imply that owners do not need to control the firm to achieve their consumption objectives. The firm's owners can realize the value of the firm by transferring ownership to others. Separation implies that the owners of the firm are only affected by the firm through the income that the firm generates. As a result, the firm is a transferable financial asset.

47. See Fisher (1906, 1907, 1930), supra note 10. 
Firms allow for a system of complete, exclusive, and transferable property rights. Ownership of firms is complete and exclusive. Firms are divisible assets whose shares can be transferred. The transferability of shares of firms has a number of important benefits. The owners of the firm can sell their ownership to other consumers or to firms, providing liquidity to inventors and to entrepreneurs. Transfers of ownership determine the market value of the firm. Firms engage in many transactions with investors, customers, suppliers, and others. The returns to this set of transactions can be capitalized in the form of ownership shares of the corporation. The firm provides a mechanism for converting the value of future transactions into a tradable asset.

\section{Separation of Objectives Allows the Separation of Ownership and Control}

With the separation of objectives, the firm's owners can delegate decision making to managers, thus separating ownership and control. Consumer organizations such as cooperatives and basic partnerships do not separate ownership and control. More complex organizations, such as closely-held firms, corporations, and some types of partnerships allow the separation of ownership and control. ${ }^{48}$ The advantages of separating ownership and control include delegation of authority to specialized managers. In corporations, owners of the firm can delegate monitoring of the firm's managers to a board of trustees.

The separation of ownership and control allows individuals to buy and sell shares of firms. Prices in securities markets reflect investor information about the anticipated performance of the firm. The owner of the firm obtains the residual returns from the firm's earnings and exercises residual control over the firm's operations. Individuals can build portfolios of securities allowing them to obtain the benefits of diversification of investments. ${ }^{49}$ The separation of ownership and control thus enhances the ability of the firm to raise financial capital in comparison with consumer organizations. Financing investment is one of the most important functions of the firm.

Another major benefit from the separation of ownership and control is the development of a market for corporate control. The importance of the market for corporate control originally was identified by Henry Manne. ${ }^{50}$ Corporate

48. Ribstein examines more complex partnership forms, which he refers to as "uncorporations." He considers variations on the partnership form such as master limited partnerships, real estate investment trusts, private equity firms, hedge funds and venture capital funds. More complex partnerships with general governance structures are firms because they allow the separation of objectives. Larry $\mathrm{E}$. Ribstein, The Mystery of the Success of Delaware Law: The Uncorporation and Corporate Indeterminacy, 2009 U. ILL. L. REV. 131 (2009); LARRY E. RIBSTEIN, THE RISE OF THE UNCORPORATION (Oxford University Press 2009).

49. See Henry G. Manne, Our Two Corporation Systems: Law \& Economics, 53 VA. L. REV. 259 (1967).

50. Henry G. Manne, Mergers and the Market for Corporate Control, 73 J. POL. ECON. 110 (1965); 
managers operate under the supervision of the firm's shareholders, its board of directors, and investors. The firm's managers must act in shareholders' interests or they will be replaced either by the firm's current or future shareholders.

The separation of ownership and control allows for market valuation of the firm, providing information to managers, investors, and the firm's owners. The market for corporate ownership makes it easier to combine firms through mergers and acquisitions. This allows the firms' owners to obtain gains from consolidating different firms. Markets for corporate ownership make it easier to reorganize firms by divestiture, allowing the firm's owners to benefit from assigning the firm's assets and capabilities to different tasks. Some important benefits of separation of ownership and control are those associated with agency. Delegation to managers provides benefits from specialization and the division of labor. The managers of the firm are specialists in strategy, administration, and functional areas such as accounting, marketing, finance, operations, information technology, and R\&D. The managers of the firm provide knowledge and expertise, so that the firm is not limited by the capabilities of its owners. The managers of the firm devote their time and effort to management so that the firm is not limited by the opportunity costs of its owners' time and effort. Even if the business is managed by its owners, delegating authority to a specialist or consultant who manages the firm effectively realizes the benefits of agency and the separation of ownership and control.

Delegation of authority to a manager replaces multiple contracts among owners with two types of contracts. The firm's owners contract with the firm through ownership shares and in turn, the firm contracts with the manager. The firm provides transaction cost advantages when ownership shares combined with a contract between the firm and the manager are less costly than multiple contracts among members of a consumer organization. The manager unifies the control of the firm in comparison with multiple conflicting managers of a consumer cooperative or a basic partnership. The contract between the firm and the manager is a relational contract that specifies in general terms the manager's duties without the need for continuous renegotiation that might occur within a basic partnership.

Separation of ownership and control provides incentives for management that differ from consumer organizations such as basic partnerships. The firm provides the manager with incentives for performance. This relationship is subject to problems of moral hazard since the manager's effort may not be observable. The relationship is subject to problems of adverse selection since the manager may have information that is hidden from the firm's owners, such as the manager's ability. Consumer organizations experience moral hazard in 
the form of free riding and adverse selection due to asymmetric information. The relative effects of these costs determine whether there are advantages to the separation of ownership and control. The firm performs better if the transaction costs associated with agency are less than the transaction costs associated with free riding. The unity of control offered by delegation to a manager can offer benefits by replacing costly group decision making.

\section{E. Returns to Entrepreneurs}

The separation of objectives has profound implications for the establishment of firms. The resulting separation of ownership and control helps to specify the returns to entrepreneurs. After the firm is established, the entrepreneur becomes an owner of the firm. The entrepreneur realizes a return to entrepreneurship by obtaining the firm's profits once the firm is established. If there is a market for firms, the entrepreneur realizes a return by selling the firm. The return to entrepreneurship is the owner's share of the value of the firm once it is established.

As an illustration, consider an innovator who identifies an opportunity to bring an invention to market by purchasing an idea from an inventor and then selling the invention to several producers. One way to obtain the returns from this idea would be for the innovator to carry out all of necessary transactions with the inventor and the producers. The innovator would invest time and effort in completing the necessary transactions. The innovator would realize returns through contracts with the inventor and producers. Alternatively, the innovator could establish a firm to carry out the necessary transactions, thus becoming an entrepreneur. After establishing the firm, the entrepreneur would receive a share of the profits of the firm or the entrepreneur could sell the firm to investors. The value of the firm would reflect the expected return to the entrepreneur's idea. Forming a firm gives the innovator the benefit of liquidity by allowing the innovator to realize the value of an innovation by obtaining the firm's profits or by selling the firm. The choice between contracts and establishing a firm should be based on the relative efficiency of the transactions.

\section{F. The Firm Intermediates Transactions}

Firms address transaction costs both through markets and organizations. The major role that firms play in the contemporary economy suggests that firms possess substantial transaction cost advantages over direct exchange. ${ }^{51}$ The

51. See Spulber, Market Microstructure, supra note 7; Daniel F. SPUlber, The Market MAKERS: HOW LEADING COMPANIES CREATE AND WIN MARKETS (McGraw Hill 1998) (on the role of firms in establishing and operating markets and in the design of market microstructure). Spulber points out that firms provide markets with mechanisms of spontaneous order in addition to prices, including 
scope of the firm is the combination of the firm's market making and organizational activities. The role of the firm in improving transactional efficiency suggests an "intermediation hypothesis," which states that increases in consumer transaction costs relative to those of the firm lead to growth of the scope of the firm. 52 The "intermediation hypothesis" examines the economy's reliance on firms as intermediaries. The hypothesis suggests that as a result of transaction costs, the extent of the market explains the establishment of firms to replace consumer organizations and direct exchange.

The general theory of the firm yields useful insights that can be tested empirically using contemporary and historical data. The diversity of firms in the contemporary economy provides substantial information for studying the activities of firms. The "intermediation hypothesis" is complementary with the "internalization hypothesis," otherwise known as the "make-or-buy" choice, which suggests that firms address some types of transaction costs by vertical integration. This determines how the firm divides its scope between it market making activities and organizational activities.

The separation of objectives between the firm and its consumer-owners supports the firm's role as an intermediary in economic transactions. Through multilateral transactions, the firm overcomes time constraints faced by individuals. Because transactions require time and effort, individuals are likely to be restricted to bilateral interactions for spot transactions and contracts. Firms are able to offer mechanisms that handle many transactions simultaneously. Firms create markets that allow them to interact simultaneously with many customers and suppliers. Firms also create organizational structures that handle many transactions simultaneously. The separation of objectives from those of owners facilitates the formation of large-scale firms that can create efficient market mechanisms and organizations.

Consumers cannot be in two places at once. This limits their ability to engage in multiple transactions. Consumers have a limited amount of time to allocate between labor, leisure and transaction activities. It is reasonable to suppose that transactions take time, so that an individual consumer is limited in the number of transactions per unit of time. Firms overcome such time limitations through organizations with multiple members, so that firms can engage in multiple transactions simultaneously. ${ }^{53}$ The firm faces practically no limits on the number of transactions per unit of time. The application of information technology further extends the ability of the firm to enter into

marketing, sales, media and other types of mass communication. See also DANIEL F. SPULBER, GLOBAL COMPETITIVE STRATEGY (Cambridge University Press 2007) (on international business).

52. See SPULBER, MICROECONOMICS, supra note 7.

53. For example, the Federal Reserve Bank's FedWire in 2003 handled 123 million transactions with an aggregate value of $\$ 447$ trillion. James M. Lyon, Payments Evolution or Revolution? Views from the Federal Reserve, THE REGION 6-9 (2004). See also id. at 38-41. 
many transactions.

By transacting with many buyers and sellers, the firm creates a network that gives its customers access to many suppliers and its suppliers access to many customers. The firm as intermediary is thus at the center of hub-and-spoke network. ${ }^{54}$ Jensen and Meckling's view of the firm as a "nexus of contracts" reflects the efficiency of centralized contracting. ${ }^{55}$ Buyers and sellers transact with the firm in contrast to making every possible connection between individual buyers and sellers. Efficiency is improved since the number of connections is significantly lower. Efficiency is further enhanced if the firm adds additional matchmaking and communication services that reduce search costs for members of the network.

The firm has advantages over individual consumers by serving as a contracting hub. Many different types of transactions can be connected. The firm contracts with customers, suppliers, partners, investors, and employees. This simplifies the content of each transaction. For example, a customer buying a gallon of milk at a supermarket need not consider all of the underlying transactions that were necessary to establish, finance staff, and provision the store. The customer further benefits from one-stop shopping, filling a shopping basket during one transaction at the store, without the need to shop at many specialized stores for each item in the basket.

Firms can also perform clearing-house activities that consolidate transactions. In a clearing house, members make multiple trades and settle with the clearing house only the net payments. Clearing reduces the number of necessary settlements to at most one transaction per member. Banks benefit from processing payments between its own accounts, known as "on us" transactions, rather than payments between banks which double the number of transactions, referred to as "transit transactions." 56

The firm's market transactions and organizational transactions are voluntary. Firms apply market mechanisms and organizational incentives rather than command and control. The firm's customers, suppliers, and employees make decisions on the basis of their preferences, endowments, and information. The voluntary response of individuals to incentives such as prices, wages, and contracts generate "spontaneous order" in the sense of Friedrich Hayek." Market transactions are the result of voluntary agreements between buyers and

54. Such hub-and-spoke economies are well-known in marketing. See Wroe Alderson, Factors Governing the Development of Marketing Channels, in MARKETING CHANNELS FOR MANUFACTURED PRODUCTS (Richard M. Clewett ed., 1954); M. Townsend, Intermediation with Costly Bilateral Exchange, 55 REV. ECON. STUD. 417 (1978).

55. See Jensen \& Meckling, supra note 6.

56. See Sherrill Shaffer, Network Diseconomies and Optimal Structure, 5 (Fed. Reserve Bank of Philadelphia, Working Paper No. 97-19, 1997).

57. Friedrich A. Hayek, The Creative Powers of a Free Civilization, in ESSAYS ON INDIVIDUALITY (F. Morley, ed., The Liberty Fund 1977). 
sellers who receive gains from trade. Organizational transactions also are the result of voluntary agreements between the firm and its employees, who each receive gains from trade. Alchian and Demsetz emphasize the voluntary nature of employment. ${ }^{58}$ They point out that "managing, directing, or assigning workers to various tasks" is just a form of continual contract renegotiation within organizations.

\section{G. The Firm Has Longevity}

The separation of the firm's objectives from those of its owners provides the firm with an important feature. The firm overcomes the finite lifetimes of its owners. By living longer than individuals, firms can create many kinds of transactions that consumers cannot. By operating in multiple periods, firms can transfer value over time. Firms can develop transactions that connect consumers in different time periods. Firms can transfer value and goods over time through contracts with consumers and suppliers in multiple periods. Shares of the firm are tradable assets that provide a store of value to investors.

Because firms can live longer than consumers, they can invest in developing long-term reputations. In practice, the firm's name is a brand that stands for the firm's reputation for product quality, expertise, trustworthiness, or possibly a lack thereof. Such reputation effects can reduce potential problems of moral hazard or adverse selection. The long-term returns on reputation provide incentives for behavior by firms that allow transactions not necessarily available to consumers.

The longevity of firms permits investments in activities such as research and development that take a long time to bear fruit. Because firms can live longer than their employees, firms can receive returns to efforts that have a long-term payoff. Firms can reward employees for efforts whose returns may exceed the employees' tenure or even their lifetime.

Firms also can outlive their owners. This valuable aspect of longevity is reflected in the corporate form that allows owners to withdraw their capital by selling their ownership shares to others without interfering in the life of the company. Entrepreneurs earn returns from establishing a firm that outlives them. Such a transaction might be difficult to achieve through direct exchange between shorter-lived consumers.

Some consumer organizations do not have the ability to outlive their owners. For example, an individual who forms contracts with other individuals faces limits due to his own lifetime. Some basic partnerships are based on the participation of specific individuals and are disbanded if even one of the partners exits. When memberships can be transferred or individual members

58. Alchian \& Demsetz, supra note 6, at 777 . 
can be replaced, the organization takes on the properties of a firm. There are some consumer organizations that can achieve longevity. For example, a family enterprise that is managed for the consumption benefits of the family can have a long lifetime as ownership is passed down through inheritance. However, transferring control of a family firm across generations can be a difficult process subject to disagreements, conflicts, and rivalries. The establishment of a firm with its own objectives can achieve longevity through standardized mechanisms for transferring ownership.

\section{H. The Firm Offers Identity and Anonymity}

Macneil observes that practically all contracts are "relational" in that their characteristics include significant duration, close personal relations as in employment, social reputation and norms, an anticipation of future cooperative behavior, and a view that the relationship will evolve over time rather than being fully specified at the outset. ${ }^{59}$

The firm changes the nature of contracts by serving as an intermediary. Firms offer both identity and anonymity to the individuals with whom it contracts. The firm has its own name and identity that is known to its customers, suppliers, partners, and investors. The firm's identity provides returns to building a brand name and reputation, as already noted. In turn, the firm may keep track of the identity of its trading partners as a means of gathering market information.

At the same time, by serving as an intermediary, the firm often confers some amount of anonymity on its transaction partners. Although the firm and its trading partners know each others' identities, the firm allows its trading partners to retain their anonymity with each other. Customers need not know each others' identities or those of the firm's suppliers or investors. Transactions become somewhat removed from their social context in comparison with direct exchange.

To understand the intermediation role of the firm, consider two consumers who engage in direct exchange with each other. Generally, the two individuals are aware of each other's individual characteristics, including their identity, location, age, gender, appearance, income, and methods of payment. They may be acquainted with each others because they know each other socially or they may have traded together before. Such social connections may have advantages; the two consumers may have built up trust for example. However, such social connections may have disadvantages as well. The transaction may involve time-consuming conversations and social rituals that increase the costs of bargaining. The terms of trade may reflect social obligations between the

59. See MACNEIL, supra note 9; Ian R. Macneil, The Many Futures of Contracts, 47 S.C. L. REV. 691 (1974). 
parties that may prove more advantageous for some. In contrast, firms standardize transactions in terms of prices and the characteristics of goods and services. They confer anonymity on their customers and other trading partners. A customer can purchase a product at a store with a minimum of interaction beyond the transaction. This allows firms to develop markets for goods and services in which transactions are more convenient for customers and suppliers.

Firms also offer some anonymity in employment. There may be advantages working with family members or members of a social group, as in the case of merchant associations. However, there are high transaction costs involved in establishing and maintaining a team or partnership. Negotiations would be affected by family or social relationships. By standardizing employment relationships, firms allow potential employees to develop standard skills that can be offered to different firms. Firms standardize wages and job descriptions for potential employees. Firms organize labor markets by making employment relationship more convenient for employees.

\section{The Firm Realizes Economies of Scale from Specialization and Division of Labor}

By maximizing profits, firms make the management and strategic decisions necessary to take advantage of economies of scale that derive from specialization and division of labor. Consumer organizations such as workers cooperative may pursue different objectives in choosing the size of their memberships so that they do not necessarily obtain the full benefits of economics of scale.

Many different types of firms are specialists in particular types of transactions. Their great variety of economic transactions helps to explain the many types of firms in the economy. A buyer forms a contract with a seller to obtain a future service. A factory owner engages workers and coordinates their productive efforts to manufacture a good. A contractor engages skilled labor to complete a project. A principal hires an agent, often to represent the principal in a further transaction with a third party. An investor provides financing for a productive activity. Practically any economic activity from exchange to manufacturing can be fully described in terms of transactions.

The specialization and division of labor in society that Adam Smith emphasized is enhanced by adding firms to the population of consumers. Entrepreneurs can establish a firm to undertake a highly specific task. Firms can specialize in particular types of transactions in a manner that may not be feasible for consumers. A consumer may purchase a wide variety of goods. A consumer may have diverse interests, combining labor and leisure pursuits. Consumer-owners can invest in a specialized firm, while holding a diverse portfolio of other investments.

The specialist firm improves transactions by developing expertise in 
completing a particular type of exchange. Firms employ and train personnel with the necessary skills to develop knowledge within the organization needed to conduct a particular type of business. Firms develop business routines to carry out repetitive tasks, such as production assembly lines or check out stands at retail stores. Chandler identifies organizational capabilities in management strategy and in functional areas such as innovation, marketing, and purchasing. ${ }^{60}$ As a result of specialization, firms can get better at communicating, learning, and making decisions.

The specialist firm takes advantage of economies of scale and scope in transaction technology. Firms have fixed costs of transactions, that is, the costs do not depend on the volume of transactions, such as information-processing equipment. ${ }^{61}$ Firms can also take advantage of many sources of economies of scale including automation, standardization of the terms of transactions, and specialization and division of labor in processing transactions. Firms can obtain economies of scope by using such methods to handle a variety of different transactions. For example, a retailer handles many different products with a common transaction technology. The specialist also benefits from network economies as a center of transaction activity. Specialists also take advantage of market information obtained by handling many similar transactions.

\section{IMPLICATIONS OF THE SEPARATION THEORY OF THE FIRM FOR CORPORATE LAW}

The separation theory of the firm has important implications for the analysis of corporate law. The separation theory of the firm places emphasis on the full range of transaction costs faced by owners of the firm. Many of these transaction costs should be approached within the context of property rights. This extends and supplements the contractarian approach to corporate law, which places emphasis on the transaction costs of contracting with the firm's managers.

The contractarian analysis of corporate law devotes considerable attention to agency costs, that is, the transaction costs of delegating authority to managers. The firm incurs agency costs in the form of shirking by managers,

60. CHANDLER, supra note 17.

61. Banks have economies of scale in handling accounts and processing transactions. See empirical studies in C. W. Sealey, Jr. \& James T. Lindley, Inputs, Outputs, and a Theory of Production and Cost at Depository Financial Institutions, 32 J. FIN. 1251 (1977); Thomas W. Gilligan, Michael L. Smirlock, \& William Marshall, Scale and Scope Economies in the Multi-Product Banking Firm, 13 J. MONETARY ECON. 393 (1984); Gary D. Ferrier \& C. A. Knox Lovell, Measuring Cost Efficiency in Banking: Econometric and Linear Programming Evidence, 46 J. ECONOMETRICS 229 (1990). Advertising agencies have economies of scale and scope deriving from transactions in placing media advertisements for their clients. See Alvin J. Silk \& Ernst R. Berndt, Costs, Institutional Mobility Barriers, and Market Structure: Advertising Agencies as Multiproduct Firms, 3 J. ECON. \& MGMT. STRATEGY 437 (1994). Retail stores use computers, cash registers, bar coding and point-of-sale terminals. 
inaccurate reporting of information by managers, and managerial rent seeking. ${ }^{62}$ Managerial rent seeking can be interpreted within the contractual framework as breaches of the duties of care and loyalty. The firm incurs costs of providing incentives for managers and in monitoring management performance. This view of corporate law emphasizes the potential for managers to evade supervision by the board of directors and by shareholders so as to increase their compensation and disguise bad managerial decisions. Based on this approach, public policy is directed at increasing the power of shareholders and corporate boards relative to management.

The separation theory of the firm clearly identifies the objectives of the corporation and those of the firm's shareholders. It suggests that corporate law provides a template that improves the efficiency of transactions associated with the exercise of property rights by the firm's owners. Corporate law provides a context for corporate governance by the firm's shareholders, corporate directors, and managers. Additionally, corporate law provides a framework for the market for corporate control.

\section{A. Property Rights}

The separation theory of the firm highlights the connection between corporate law and the property rights of investors. Corporate law seeks to improve transaction efficiencies by providing a standard legal form. ${ }^{63}$ Among the features of the standard form are the delegation of authority by shareholders to management and delegation of monitoring to a board of directors. The standard form also has implications for owners' rights to residual returns and rights of residual control.

The separation criterion approach shares features with both the contractual and the property approach to firms. It is generally recognized that securities involve both contract rights and property rights. Contract rights and property rights reflect different regulatory strategies. ${ }^{64}$ These rights derive from investor ownership of the corporation's securities. Many features of the standard

62. See, e.g., Lucian Arye Bebchuk, Jesse M. Fried \& David I. Walker, Managerial Power and Rent Extraction in the Design of Executive Compensation, 69 U. CHI. L. REV. 751 (2002); Andrei Shleifer \& Robert Vishny, Management Entrenchment: The Case of Manager-Specific Investments, 25 J. FIN. ECON. 123 (1989); Andrei Shleifer \& Robert Vishny, A Survey of Corporate Governance, 52 J. FIN. 737 (1997).

63. See Frank Easterbrook \& Daniel R. Fischel, The Economic Structure of Corporate LAW (Harvard University Press 1991); Ribstein, Why Corporations?, supra note 31.

64. For a discussion distinguishing contracts rights from property rights, see Thomas $\mathrm{W}$. Merrill and Henry E. Smith, The Property/Contract Interface, 101 CoLUM. L. REV. 773, 790 (2001) (arguing that "[i]n personam contract rights and in rem property rights can be seen as two different strategies for regulating the use of resources," with in personam contract rights used for governance and in rem rights used for exclusion); Thomas W. Merrill \& Henry E. Smith, What Happened to Property in Law and Economics?, II 1 YALE L.J. 357 (2001). On implications for monitoring by investors, see Thomas H. Jackson \& Anthony T. Kronman, Secured Financing and Priorities Among Creditors, 88 YALE L. J. 1143 (1979). 
corporation have a distinct property rights flavor. Investors have ownership rights that entitle them to receive the firm's residual returns. Investors' ownership rights also give them residual rights of control over the firm. Investor's ownership rights are complete, exclusive, and transferable. Although financial contracts are tradable, as is the case with futures and options, the transferability of corporate securities corresponds closely with the transfer of ownership. Investor's limited liability can be examined within the context of property rights.

The separation criterion approach is consistent with many of the conclusions of the contractarian perspective. The separation criterion approach views the organizational and contractual structure of the firm as the result of the same competitive market forces. The contracts and ownership structure of the newly-established firm reflects agreements between the entrepreneur and the firm's investors. ${ }^{65}$ The contracts and ownership structure of existing firms reflect voluntary agreements involving investors, owners, directors, and managers.

The contractarian approach to corporate law emphasizes the contracts between the firm and its directors and managers. ${ }^{66}$ These contracts provide incentives to directors and managers to act in the interests of shareholders. Asymmetries in information lead to problems of moral hazard and adverse selection that can cause the interests of directors and managers to depart from those of shareholders.

The separation approach also emphasizes the property rights of the corporation's shareholders. Application of the separation criterion implies that the corporation should be structured to improve the ability of owners to maximize the income that they receive from their share of the firm's residual returns. The corporation also should be structured to improve the ability of its owners to delegate authority to management and to exercise rights of residual control. The corporation's rules apply to voting, the corporate board, sales of securities, disclosure of information, and the settlement of claims resulting from financial distress.

Henry Hansmann and Reinier Kraakman ask "what, if any, essential role does organizational law play in modern society." 67 They further ask "do the various legal entities provided by organizational law permit the creation of relationships that could not practicably be formed by contract alone?"68

65. Easterbrook and Fischel point out that in establishing the firm, the entrepreneur faces two important questions: "what promises to make" and "how to induce investors to believe them." EASTERBROOK \& FISCHEL, ECONOMIC STRUCTURE, supra note 63, at 5.

66. See Jensen \& Meckling, supra note 6; EASTERBROOK \& FiSCHEL, ECONOMIC STRUCTURE, supra note 63.

67. See Henry Hansmann \& Reinier Kraakman, The Essential Role of Organizational Law, 110 YALE L.J. 387 (2000).

68. Id. 
Hansmann and Kraakman argue that the main role of organizational law is asset partitioning. ${ }^{69}$ Not only are investors' assets protected from claims of the corporation by limited liability, the converse is also the case. The assets of the corporation, and the personal assets of its owners and managers, are protected from claims by investors. Effectively, organizational law establishes a system of property rights for the corporation, rather than just rules for contracts. Hansmann and Kraakman emphasize that: "the separation between the firm's bonding assets and the personal assets of the firm's owners and managers-is the core defining characteristic of a legal entity, and establishing this separation is the principal role that organizational law plays in the organization of enterprise." 70

\section{B. Corporate Governance}

The separation theory of the firm distinguishes the institution's objectives from the consumption objectives of its owners as well as from those of other parties that contract with the firm. This differs from the contractarian perspective, in which the firm's objectives emerge from the collection of voluntary contracts between many individuals. Corporate law should facilitate organizational forms that carry out the separation of the firm's objectives from the consumption objectives. If individuals wish to establish an organization such as a club or workers' cooperative that does not separate these objectives, they can pursue organizational forms that differ from the corporation.

The objectives of the contractarian firm are those of all of the parties to its various contracts. Easterbrook and Fischel point out that the contractual approach "does not draw a sharp line between employees and contributors of capital."71 They argue that the maximand of the corporation is the result of contractual choices, which reflect private contractual agreements. ${ }^{72}$ Because they are voluntary, these agreements necessarily seek to achieve gains from trade for the participants. Corporate law should be neutral with regards to the firm's objectives to the extent that the firm's maximand is the outcome of market forces. Based on this approach, Easterbrook and Fischel suggest that the role of corporate law is "to provide a background term that prevails unless varied by contract:",73

An approach that emphasizes the contractual nature of the corporation removes

69. See Hansmann \& Kraakman, supra note 67; Henry Hansmann \& Reinier Kraakman, Organization Law as Asset Partitioning, 44 EUR. ECON. REV. 807 (2001).

70. Hansmann \& Kraakman, supra note 67. Also, Hansmann et al examine the development of asset separation shielding the firm in ancient Rome, medieval Italy, early modem England, and the contemporary United States. See Henry Hansmann, Reinier Kraakman, \& Richard Squire, Law and the Rise of the Firm 1-63 (Eur. Corp. Governance Inst. Working Paper Series in Law, No. 57/2006, 2006).

71. EASTERBROOK \& FISCHEL, ECONOMIC STRUCTURE, supra note 63, at 37.

72. Id.

73. Id. at 36 . 
from the field of interesting questions one that has plagued many writers: what is the goal of the corporation? Is it profit, and for whom? Social welfare more broadly defined? Is there anything wrong with corporate charity? Should corporations try to maximize profit over the long run or the short run? Our response to such questions is: who cares? ${ }^{74}$

However, this begs the question of why corporate law is needed to supplement contract law. Corporate law should perhaps provide more guidance. There are many possible "background terms" that are consistent with freedom of contract. The separation criterion definition of the firm presented goes beyond the contractual view by addressing the maximand of the corporation. The firm's maximand need not be profit maximization but it should be distinct from that of its owners. The corporation should not be a mechanism for providing consumption benefits to its owners, either in the form of lower prices for owners who are buyers or higher payments and perks for owners who are managers and employees.

The separation theory of the firm characterizes the institution as a distinct economic actor that pursues objectives. The firm is defined by the ability to separate the objectives of the institution from the consumption objectives of its owners. Satisfying the separation criterion generally implies but does not require profit maximization. Profit maximization should emerge from separation, as Fisher emphasized. Corporate law recognizes that the firm pursues its own objectives with management acting under authority delegated by its owners.

The separation criterion view draws a distinction between employees and providers of capital. This does not mean that such a distinction should be enforced by law, since contracts are voluntary. Rather, the corporate form should recognize the need to separate the firm's maximand from that of its owners, whether these are investors or employees. If the owners of the firm do not wish to make such a separation, then they should choose to adopt other institutional forms, such as cooperatives or nonprofits, which have different background terms.

The separation theory of the firm suggests that corporate law provides "standard terms" that facilitate corporate governance. The firm's owners seek to maximize their net income, which reflects their residual claims net of the transaction costs of exercising property rights. Corporate governance involves more than the costs of delegating authority to the firm's managers. Corporate governance rules affect the residual returns and the transaction costs associated with conflict between shareholders, between shareholders and the board, and between shareholders and management. Corporate governance rules additionally recognize the benefits to shareholders of delegating authority to the corporation's board and to managers, including limited expertise of 
shareholders and the opportunity costs of shareholders' time.

\section{The Market for Corporate Control}

Corporate law provides "standard terms" to the market for corporate control. The separation theory of the firm places emphasis on property rights that are the foundation of securities markets. The firm's owners sell securities that provide rights to residual returns and residual control. By setting rules for disclosure of information, mergers and acquisitions, and takeovers, corporate law affects transaction costs in the market for securities. When securities markets function efficiently, securities prices reflect the information about the future performance of companies.

Limited liability is a key aspect of corporate law. ${ }^{75}$ The separation criterion helps to explain the importance of limited liability. When separation holds, limited liability means that only the value of their investment affects the firm's owners' consumption and savings decisions. With separation, limited liability thus implies that the firm's owners want managers to maximize the value of the firm. With separation, limited liability allows the formation of a market for securities.

Corporate law provides incentives for the firm to accumulate enterprisespecific physical capital, organizational capital, and human capital. ${ }^{76}$ Margaret Blair points out that corporate law performs an important function by giving the firm entity status through the separation of ownership and control. ${ }^{77}$ The entity perspective emphasizes that the firm has value as an ongoing concern. The separation of ownership and control provided by corporate law allows investors to withdraw capital without necessarily blocking the continued operation of the firm. Also, managers can withdraw from the firm without necessarily changing its continued operation. Investors and managers need not have their decisions dependent on how their withdrawal affects the survival of the entity as in the case of the basic partnership.

The question of separation of ownership and control has generated some

75. Easterbrook and Fischel state that limited liability is "perhaps the distinguishing feature of corporate law." EASTERBROOK \& FISCHEL, ECONOMIC STRUCTURE, supra note 63, at 40. However, as they recognize limited liability also applies to debt investors in sole proprietorships, general or limited partnerships, business trusts and other ventures. They further recognize limited liability holds for equity investors in limited partnerships and business trusts, and limited liability applies to employees and other contributors of human capital for any organizational form.

76. See MARGaret M. Blair, OWNERSHIP AND CONTROL: RETHINKING CORPORATE GOVERNANCE FOR THE TWENTY-FIRST CENTURY (Brookings Institution 1995); Margaret M. Blair, Locking in Capital: What Corporate Law Achieved for Business Organizers in the Nineteenth Century, 51 UCLA L. REV. 387 (2003); Margaret M. Blair, The Neglected Benefits of the Corporate Form: Entity Status and the Separation of Asset Ownership From Control, in CORPORATE GoVERNANCE AND FIRM ORGANIZATION: MiCROFOUNDATIONS AND STRuCtuRAL Forms 45-66 (Anna Grandori ed., Oxford Univ. Press 2004).

77. See Blair, Locking in Capital, supra note 76; Blair, Neglected Benefits, supra note 76. 
controversy. Although corporations are the main form of organization in developed economies, they have traditionally been the object of criticism. Adam Smith observed that directors of joint-stock companies:

[B]eing the managers rather of other people's money than of their own, it cannot well be expected, that they should watch over it with the same anxious vigilance with which the partners in a private copartnery frequently watch over their own.... Negligence and profusion, therefore, must always prevail, more or less, in the management of the affairs of such a company. ${ }^{78}$

The inefficiencies of the corporate form are a frequent theme in the economics, finance, and law literatures. A large literature on corporate governance offers myriad suggestions for private reforms and public regulation. ${ }^{79}$

In their classic study, Adolf Berle and Gardiner Means expressed concern that the separation of ownership and control would replace efficient markets with inefficient corporations. ${ }^{80}$ They argued that dispersed ownership would lead to a divergence, and even opposition, of interests between owners and managers and also noted the general absence of dominant shareholders. Berle and Means maintained that diffused ownership reduced the incentives for shareholders to monitor management in comparison to a closely-held company. For Berle and Means, this situation represented a corporate revolution that outdid the effects of the industrial revolution. Because of the separation of ownership and control, the management of corporations exercised significant autonomy and consequently might not maximize profit. Means indeed attributed the Great Depression to the corporate revolution, which in his view led to inflexible "administered prices." Administrative action by managers replaced market forces in determining prices, "thus inhibiting any general fall in the price level and converting a general fall in demand into a recession and unemployment." ${ }^{\text {" }}$ Corporate scandals have led to public policy debates regarding the efficiency of the corporate form. Regulation by the Securities and Exchange Commission and laws such as the Sarbanes-Oxley Act reflect these continued concerns.

78. ADAM SMITH, AN INQUiRy INTO THE NATURE AND CAUSES OF THE WEALTH OF NATIONS 850 (Regnery Publishing 1998) (1776).

79. See, e.g., Blair, OWNERSHIP AND CONTROL, supra note 76; MACAVoY \& MillsteIn, supra note 2 .

80. See Adolf A. Berle \& Gardiner C. Means, The Modern Corporation and Private PROPERTY (Harcourt, Brace \& World 1967) (1932).

81. See Gardiner C. Means, Implications of the Corporate Revolution in Economic Theory in the introduction to BERLE \& MEANS, THE MOdERN CORPORATION, supra note 80. See also Gardiner C. Means, The Consumer and the New Deal, 173 ANNALS AM. ACAD. POL. \& SoC. SCI. 7 (1934); Gardiner C. Means, The Major Causes of the Depression, in HeTERodox ECONOMICS OF GARDiner C. MEANS: A COLleCtion 73-92 (Frederic S. Lee \& Warten J. Samuels, eds., M. E. Sharpe, Inc. 1992) (1935); Gardiner C. MEANS, The STRUCtURE OF AMERICAN ECONOMY (Augustus M. Kelley Publishers 1966) (1939); Gardiner C. Means, Big Business Administered Prices, and the Problem of Full Employment, 4 J. MARKETING 370 (1940). 
The Berle and Means view is inconsistent with the success of the corporate form of organization. As Jensen and Meckling observe, "Whatever its shortcomings, the corporation has thus far survived the market test." to Berle and Means, Demsetz and Lehn find no correlation between accounting profits and concentration of ownership. ${ }^{83}$ Corporations attract large amounts of investment and remain the dominant form of organization for firms. The fact that corporations are the main form of business organization strongly suggests that they provide greater economic benefits than other institutional arrangements.

Jensen and Meckling, based on the principal-agent model, emphasize the effects of incentives on the performance of managers. ${ }^{84}$ As the agent of the corporation's shareholders, the manager is subject to moral hazard problems. If the manager has a substantial ownership share, the manager will be overly cautious and will avoid risky projects that might increase the firm's expected value. If the manager has a small ownership share, the manager may shirk in terms of insufficient effort or in terms of excessive perks. The manager's actions may depart from the interests of shareholders in various ways. The manager may not devote sufficient effort to his tasks, the manager may not accurately share information with owners, the manager may have a time horizon that is too short, the manager many avoid risk, and the manager may overinvest in the firm's activities rather than distributing returns to shareholders. $^{85}$

Following the contracts perspective, Easterbrook and Fischel recommend that courts be guided by an implicit but efficient contract in which the firm's owners seek jointly to maximize their wealth. ${ }^{86}$ Fischel argues that courts should be guided by the role of the manager as a fiduciary, that is, the manager is guided by the duties of loyalty and care. ${ }^{87} \mathrm{He}$ observes that "optimal

82. Jensen \& Meckling, supra note 6 , at 357.

83. See Harold Demsetz and Kenneth Lehn, The Structure of Corporate Ownership: Causes and Consequences, $93 \mathrm{~J}$. POL. ECON. 1155 (1985). In response to the Berle and Means argument, Demsetz points out that the firm's owners have an incentive to align the managers' interests with their own, including giving ownership shares to management. Harold Demsetz, The Structure of Ownership and the Theory of the Firm, 26 J. L. \& ECON. 375 (1983). Ruback and Jensen (1983) point out that the market for corporate control involves not only competition between potential owners of the firm, but also competition between potential managers for the opportunity to manage corporate resources. Richard S. Ruback \& Michael C. Jensen, The Market for Corporate Control: The Scientific Evidence, 11 J. Fin. ECON. 5 (1983). They show empirically that corporate takeovers generate gains from trade, both for target shareholders and acquiring firm shareholders, and that these gains come from efficiency rather than market power.

84. See Jensen \& Meckling, supra note 6. For additional discussion of the agency approach to corporate govemance, see Indraneel Chakraborty, Heterogeneity in Corporate Governance: Theory and Evidence (Univ. of Pa., Wharton Sch., Fin. Dept., 2007).

85. See Henry Butler, Contractual Theory of the Corporation, 11 GEo. MASON L. REV. 99 (1989).

86. See Frank H. Easterbrook \& Daniel R. Fischel, The Corporate Contract, 89 CoLUM. L. REV. 1418 (1989); EASTERBROOK \& FISCHEL, ECONOMIC STRUCTURE, supra note 63.

87. See Daniel R. Fischel, The Corporate Governance Movement, 35 VAND. L. REV. 1259 (1982). 
fiduciary duties should approximate the bargain that investors and managers would reach if transaction costs were zero." 88 However, Easterbrook and Fischel observe that "Fiduciary principles are uncommon in contractual relations." 89 This suggests that the contractual analysis of corporate law cannot fully explain the fiduciary principles applied to management.

The restrictions on the actions of CEOs in Sarbanes-Oxley reflect the agency perspective on the firm. For example, the act requires CEOs to certify the information their firm's financial statements provide to investors. The act provides a regulatory solution that attempts to enforce the manager's duties of loyalty and care. This approach places emphasis on the firm's agency contract with management. The agency approach seeks to mitigate the transaction costs of monitoring and rewarding the CEO.

The transaction costs of delegating authority to management are only one aspect of corporate governance - there are also benefits from delegation. Legal measures such as Sarbanes-Oxley are designed to reduce shirking and misrepresentation by management. Focusing legal measures on management performance may serve to raise the costs of delegation without necessarily reducing malfeasance. When firms encounter higher costs of delegation, they may not be able to capture the benefits of delegation. Firms may design organizations to avoid onerous compliance costs and in the process reduce the delegation of authority.

Corporate law should also recognize the benefits of delegating authority to management. The benefits include the development of management expertise from specialization and the division of labor, avoiding the opportunity costs of involving owners in management decisions, and the ability of managers to respond flexibly to market and technological contingencies. Delegating authority provides efficiency gains from diffuse ownership, including the liquidity of financial markets and the ability of investors to diversify their risk by holding many securities in their portfolios.

Delegation of authority to a manager also allows the owners of a corporation to benefit from unity of control. The manager of the firm can

88. See Fischel, supra note 87 , at 1264. Kornhauser finds that contracts and trust offer two metaphors for understanding corporations that "lead us awry or abandon us altogether through ambiguity." Lewis A. Komhauser, The Nexus of Contracts Approach to Corporations: $A$ Comment on Easterbrook and Fischel, 89 COLUM. L. REV. 1449 (1989). Kornhauser argues that the contracts view is problematic because in practice there are transaction costs and information asymmetries in contracting. Id. He adds that trust falls short because of the multitude of corporate principals including directors, shareholders, and bondholders, who have conflicting interests. Id. Kornhauser argues for mandatory rules that restrict the types of bargains parties can strike when the corporation is formed, thus allocating rights over the life of the corporation. Id. This approach would complement trust as a means of reducing contracting costs. Butler points out that corporate owners and managers will find the optimal mix of market and legal restraints on agency costs through direct negotiation of contracts and through the market for corporate control. Butler, supra note 85.

89. See EASTERBROOK \& FISCHEL, ECONOMIC STRUCTURE, supra note 63, at 90. 
respond flexibly and quickly to market conditions. Unity of control avoids the high transaction costs, the possibility of conflicts, and the likely free riding that would prevent large groups of shareholders from making management decisions. Shareholder voting applies to broad resolutions on proposals made by the corporate board rather than to detailed management activities.

The separation of the corporation's objectives from the consumption objectives of its owners provides a basis for the market for corporate control. The market for securities provides performance incentives for managers because investors can acquire the firm and replace managers that do not perform well. Performance incentives from the market for corporate control supplement contractual incentives for managers. The separation theory of the firm emphasizes the property aspects of the market for corporate control.

\section{COMPARISON WITH ALTERNATIVE DEFINITIONS OF THE FIRM}

It is worthwhile to contrast the general theory of the firm that is based on the separation criterion with the main economic views of the firm. There are many aspects in common and some key differences. The key difference is that the separation criterion helps to explain why firms exist by addressing their economic role in comparison with consumer organizations and direct exchange. The separation criterion helps to explain the scope of the firm. The intermediation hypothesis suggests that the firm provides a combination of market transactions and organizational transactions to improve economic efficiency. Firms must generate greater transaction efficiency relative to direct exchange between consumers. The general theory of the firm presented here also includes various transactions-costs explanations for the internalization hypothesis that explains the boundaries of the firm, including bargaining costs, search costs, moral hazard, adverse selection, hold-up, and free riding. The relative importance of transaction costs in determining the scope and the boundaries of the firm requires empirical investigation.

\section{A. The Neoclassical and Industrial Organization Theories of the Firm}

The traditional economic concept of the firm, known as the neoclassical firm, defines the firm by its production technology. ${ }^{90}$ The neoclassical firm is distinguished from the household because the household does not engage in production. ${ }^{91}$ The technological description of the firm is an engineering conception of a mechanism for transforming inputs into outputs. Moreover, neoclassical economics adds the requirements that the firm takes prices as givens and chooses inputs to minimize costs. This view underpins the

90. See ARROW \& HAHN, supra note 6

91. Id. 
benchmark of the "perfectly competitive" firm. Against this benchmark, firms that adjust their prices must have monopolistic market power, even though in practice practically all firms are able to adjust their prices. Although the perfect competition benchmark is fundamentally inconsistent with such normal pricing behavior, departures from competitive pricing are used to justify regulation and antitrust scrutiny. In addition, the neoclassical benchmark ignores various activities of the firm including marketing and management.

The neoclassical firm is a simplified construct that is far from an accurate description of the firm. In practice, firms tend to have the power to adjust their own prices, even in highly competitive markets. The firm is much more than a production technology. As Schumpeter notes, the general equilibrium perspective does not include entrepreneurship and innovation. ${ }^{92}$ The point of departure between the present discussion and the neoclassical perspective is that firms are no longer defined by their production technology. Production technology is just that, and individuals acting together or in concert can operate the production technology, thus eliminating the neoclassical distinction between the firm and the household. In contrast, the separation theory of the firm emphasizes the firm's ability to carry out transactions in comparison to consumer organizations and direct exchange.

The neoclassical and industrial organization views have much in common because they both characterize the firm based on its production technology. However, the field of industrial organization modifies the neoclassical view of the firm by recognizing that the conduct of firms affects market prices. Industrial organization models of "imperfect competition" differ from the neoclassical "perfect" competition framework in which firms take prices as given. The industrial organization conception of the firm recognizes that firms engage in strategic price competition.

The industrial organization firm not only adjusts its prices, but also chooses its product features and changes its technology through research and development and innovation. Although economists have recognized that firms benefit from economies of scale at least since Adam Smith, the industrial organization approach emphasizes the effects of economies of scale on competition between firms. The industrial organization view emphasizes strategic interaction between firms and the effects of entry decisions on market structure. This view is associated with the rule of reason approach to antitrust rather than per se prohibitions, particularly regarding vertical restraints. The rule of reason approach looks at the competitive behavior of firms rather than deducing their competitiveness by a simple analysis of market structure. ${ }^{93}$

92. SCHUMPETER, supra note 14.

93. See, e.g., Robert H. Bork, The Antitrust Paradox (Free Press 1993) (1978); Richard A. Posner, The Chicago School of Antitrust, 127 U. PA. L. REV. 925 (1979); DANIEL F. SPULBER, REGULATION AND MARKETS (MIT Press 1989). 


\section{B. The Transaction Cost Theory of the Firm}

Transaction cost economics in its various forms has had a substantial influence on jurisprudence. Its influence continues in the decisions of the Roberts Court. ${ }^{94}$ Transaction cost economics views the boundaries of firms as the result of decisions to vertically integrate productive activities to avoid the alternative of costly market contracts. The "Chicago School," which describes a combination of the industrial organization and transaction-cost approaches, has been highly influential. ${ }^{95}$ A competing approach, sometimes referred to as the "Post-Chicago School," applies game-theoretic tools to classify various competitive strategies of firms as anticompetitive. The "Post-Chicago School" suggests market conditions that justify antitrust enforcement and regulation. The "Chicago School" and the "Post-Chicago School," whatever their policy differences, share a common view of the firm based on industrial organization and transaction cost economics. ${ }^{96}$

The most important contribution to the transaction cost view of the firm is that of Ronald Coase, who emphasizes that the boundaries of the firm are determined by the transaction costs of using the market in comparison with the firm's internal costs. 97 Coase states that "a firm will tend to expand until the costs of organizing an extra transaction within the firm become equal to the costs of carrying out the same transaction by means of an exchange on the open market or the costs of organizing in another firm." 98

Coase emphasizes that firms engage in economic planning within the organization. As Coase points out: "Marshall introduces organization as a fourth factor of production; J. B. Clark gives the coordinating function to the entrepreneur; Knight introduces managers who coordinate. As D. H. Robertson points out, we find "islands of conscious power." 99 Focusing on the firm's

94. See Joshua D. Wright, The Chicago School, Transaction Cost Economics, and the Roberts' Court's Jurisprudence (George Mason Law \& Econ. Research Paper No. 08-33, forthcoming 2010); The Elgar Companion to Transactional Cost Economics (Peter G. Klein, Michael E. Sykuta, eds., Edward Elgar Publishing, forthcoming).

95. See Posner, supra note 93; William H. Page, The Chicago School and The Evolution of Antitrust: Characterization, Antitrust Injury, and Evidentiary Sufficiency, 75 VA. L. REV. 1221 (1989); William E. Kovacic \& Carl Shapiro, Antitrust Policy: A Century of Economic and Legal Thinking, $14 \mathrm{~J}$. ECON. PERSP. 43 (2000); Jonathan B. Baker \& Timothy F. Bresnahan, Economic Evidence in Antitrust: Defining Markets and Measuring Market Power (Stanford Law Sch., Working Paper No. 328, 2006).

96. Joshua Wright finds that the "Chicago School's" influence dominates that of the "Post-Chicago School" in the Roberts Court. He relies on the Court's decisions in Leegin Creative Leather Products, Inc. v. PSKS, Inc. (2007) - regarding resale price maintenance, Weyerhaeuser Co. v. Ross-Simmons Hardwood Lumber Co. (2007) - regarding predatory pricing, and Bell Atlantic Corp. v. Twombly (2007)- regarding exclusive territories. See Wright, supra note 94. See also Joshua D. Wright, The Roberts Court and the Chicago School of Antitrust: The 2006 Term and Beyond, 3 COMPETITION POL'Y INT'L 24 (2007).

97. See Coase, 1937, supra note 6; Coase, 1988, supra note 6; Coase, 1994, supra note 6.

98. See Coase, 1937, supra note 6.

99. See id. 
internal activities (rather than on its external activities), Coase asserts that "the distinguishing mark of the firm is the supersession of the price mechanism" and assigns organizational activities to the entrepreneur-coordinator. ${ }^{100}$ In the general theory of the firm presented here, the firm's external market making activities also reflect conscious power and coordination.

Because firms incur internal costs as well as market transaction costs, the firm must decide how to divide its activities between its organization and markets. For example, a firm can manufacture its own parts and components or engage in market transactions with an independent supplier. For any given scope of activities, such a division determines the firm's extent of vertical integration. The extent of vertical integration refers to the activities carried out by the firm's organization. These internal activities often are referred to as the "boundaries of the firm" but might more accurately be termed the "boundaries of the organization."

Based on Coase's path-breaking insights, the "internalization hypothesis" states that firms will substitute organizational transactions for market transactions when doing so lowers transaction costs. Economic analysis of firms has focused much attention on explaining vertical integration. The comparison of market transactions and organizational transactions is an important theme in the literature on institutional economics. ${ }^{101}$ An important distinction is made between bargaining transactions, which take place in the market, and managerial transactions, which take place within the organization. ${ }^{102}$ The empirical literature on the firm has extensively tested the effects of transactions costs on vertical integration. The "internalization hypothesis" posits that increases in market transaction costs, relative to the firm's organization costs, explain greater internalization of those transactions through vertical integration. ${ }^{103}$

100. See id.

101. See Commons, supra note 9; Coase, 1937, supra note 6; Coase, 1988, supra note 6; Coase, 1994, supra note 6; WILLIAMSON, MARKETS AND HIERARCHIES, supra note 6; WILLIAMSON, ECONOMIC INSTITUTIONS, supra note 6; SPULBER, supra note 7; EIRIK G. FURUBOTN \& RUDOLF RICHTER, INSTITUTIONS AND ECONOMIC THEORY: THE CONTRIBUTION OF THE NEW INSTITUTIONAL ECONOMICS (Univ. of Michigan Press, 2000).

102. According to John R. Commons, "Transactions, as derived from a study of economic theories and of the decisions of courts, may be reduced to three economic activities, distinguishable as bargaining transactions, managerial transactions and rationing transactions." Commons, supra note 9. Finally, Commons refers to rationing transactions as those originating from courts, legislatures or regulatory bodies. Id. For Commons, "The bargaining transaction derives from the familiar formula of a market, which, at the time of negotiation, before goods are exchanged, consists of the best two buyers and the best two sellers on that market." Id. In the case of managerial transactions "by which wealth itself is produced," there are hierarchical relationships: "The master, or manager, or foreman, or other executive, gives orders - the servant or workman or other subordinate must obey." $I d$.

103. Harold Demsetz suggests that since making and buying each entail both management and transaction costs, the question is "whether the sum of management and transaction cost incurred through in-house production is more of less than the sum of management and transaction cost incurred through purchase across markets, since either option entails expenditures on both cost categories." Harold Demsetz, The Theory of the Firm Revisited, in THE NATURE OF THE FIRM 159 (Oliver E. Williamson \& 
Coase emphasizes vertical integration as a means of avoiding the "disadvantages" of using the markets, which he refers to as the price mechanism. ${ }^{104}$ The costs of market transactions that Coase identifies include the use of short-term contracts in comparison with longer-term contractual relations within the firm. ${ }^{105}$ The firm has a wide range of mechanisms within its organization that differ fundamentally from what can be done in the market place, either between the firm and its trading partners or between consumers engaged in direct exchange. These mechanisms can lower the costs of organizational transactions relative to market transactions. ${ }^{106}$

Coase finds that firms carry out various production tasks to reduce the costs of searching for prices, negotiating individual transactions, and specifying contingencies in long term contracts. ${ }^{107}$ Thus, "by forming an organization and allowing some authority (an 'entrepreneur') to direct the resources, certain marketing costs are saved". ${ }^{108}$ Coase adds that " $[\mathrm{t}]$ he main reason why it is profitable to establish a firm would seem to be that there is a cost of using the price mechanism." 109 Coase observes that "[t]he most obvious cost of 'organizing' production through the price mechanism is that of discovering what the relevant prices are." 110

For Coase, the firm's make-or-buy decision is based on comparing the costs of market transactions with the costs of organizational transactions. ${ }^{111}$ If market transactions are more costly than organizational transactions, the production activity should be located within the firm. If market transactions are less costly than organizational transactions, the production activity should be located outside the firm, with the firm relying on suppliers for the good or service. Transaction costs are the determinants of the firm's collection of activities. The make-or-buy choice shows that the critical activity is not the production of goods, since any production activity could be outside or inside any particular firm. The critical activity is the transaction.

A restrictive application of transaction cost economics associated with Oliver Williamson builds on Coase's contrast between markets and the firm's internal allocation. ${ }^{12}$ This approach limits the specification of transaction costs to contractual hold-up. This approach offers a particular version of the

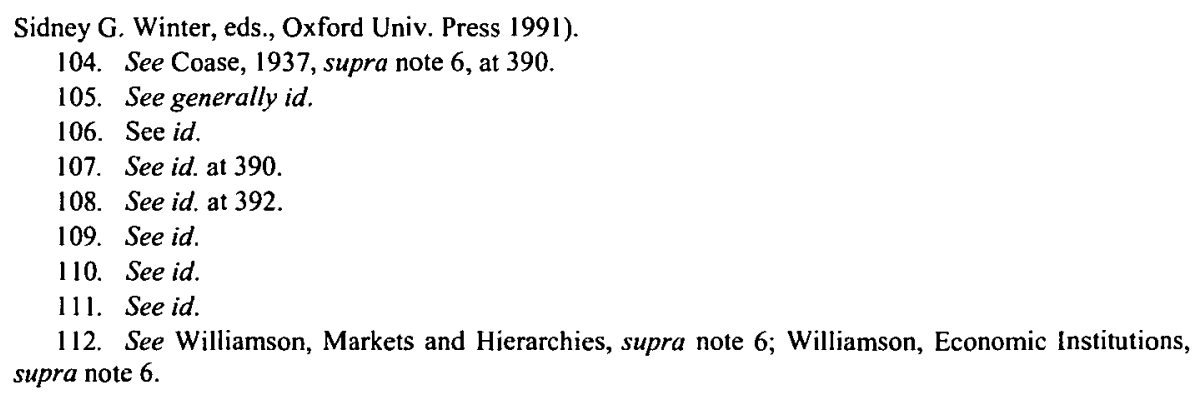


internalization hypothesis: Firms vertically integrate to overcome the inefficiencies of incomplete contracts and asset specificity.

A closely-related view of the firm explains vertical integration based on the consolidation of ownership of productive assets. ${ }^{113}$ Firms own assets to mitigate the effects of incomplete contracting and asset specificity. This view maintains that ownership of productive assets improves incentives for investment in complementary transaction-specific capital, such a human capital. For Hart, "ownership is a source of power when contracts are incomplete." 114 In a critique of this view, Holmström and Roberts point out that property rights to assets are not sufficient to explain the boundaries of the firm since market contracts can be created that replace many of the functions of vertical integration. They find that contracts in the market place can allocate decision rights thus achieving the same results as the consolidation of asset ownership. ${ }^{115}$ The firm thus chooses between market contracts and internal transactions for many reasons other than asset ownership.

\section{The Contractual Theory of the Firm}

The contractual theory of the firm extends the insights from the transaction costs view of the firm by emphasizing the firm's principal-agent contracts. The contractual theory of the firm observes that the firm enters into a "nexus of contracts" with its managers, workers, customers, suppliers, and partners. ${ }^{116}$ The firm also contracts with its investors, issuing various types of securities such as stocks, bonds, promissory notes, and debentures. The contractual theory of the firm provides the foundation for the contractarian analysis of corporate law that has heavily influenced legal and regulatory perspectives on securities markets.

The contractual theory of the firm focuses on incentives for performance of employees and managers. ${ }^{117}$ Moreover, the theory recognizes that as a consequence of asymmetric information, contracts are subject to problems of moral hazard and adverse selection. ${ }^{118}$ The contractual theory of the firm is based on the principal-agent model that emphasizes the effects of incentives on the performance of managers. As already noted previously, the manager serves as the agent of the corporation's shareholders. Due to moral hazard and adverse

113. See Sanford J. Grossman \& Oliver D. Hart, The Costs and Benefits of Ownership: A Theory of Vertical and Lateral Integration, 94 J. POL. ECON. 691 (1986); OLIVER HART, FIRMS, CONTRACTS AND FinanCIAL STRUCTURE (Oxford Univ. Press 1995); Hart \& Moore, supra note 6.

114. See Hart, supra note 113 , at 29.

115. See Bengt Holmström \& John Roberts, The Boundaries of the Firm Revisited, J. ECON. PERSP. 73 (1998)

116. See Jensen \& Meckling, supra note 6.

117. See KNIGHT, supra note 6; Alchian \& Demsetz, supra note 6; Holmström, supra note 6.

118. See Jensen \& Meckling, supra note 6. 
selection problems, the manager's incentives may not be fully aligned with those of shareholders. The manager may avoid risky projects when bearing to great a share of the firm's risk, and conversely, the manager may provide insufficient effort when not sharing in the firm's success. ${ }^{119}$

The firm incurs the direct costs of providing incentives to its employees and managers as well as the indirect costs due to shirking and incomplete revelation of information. These contracting costs can be mitigated by monitoring and coordination. Firms reduce contracting costs when they can improve contract design, monitoring, and coordination. One of the main contributions to the contractual theory of the firm is due to Armen Alchian and Harold Demsetz who explain the purpose of the firm based on the difficulties of monitoring team production. ${ }^{120}$ They describe the firm as a form of contract, with the owner as the centralized contracting actor for the team. They suggest that selfmonitoring partnerships will arise when team production requires artistic or professional skills and when there are few partners. Firms require a residual claimant as the central monitor. Firms emerge when the cost of managing the team's inputs is less than the cost of metering marginal outputs. The firm's owners are themselves monitored because they are residual claimants to the firm's profit, which is in turn subject to the discipline of the market. Alchian and Demsetz observe that the organizational structure of firms (sole proprietorship, partnership, and corporation) provides alternative ways to monitor team production.

Holmström provides a complementary contribution to the contractual theory of the firm that emphasizes the firm's role as a designer of incentives rather than as a monitor. ${ }^{121}$ As a residual claimant, the firm can employ incentive mechanisms that are not subject to budget-balancing constraints that are faced by partnerships. Although mechanisms such as penalties and rewards work well under certainty, this need not hold under uncertainty. When outcomes are subject to shocks, the efficacy of such schemes is constrained by limits on the liability of either the principal or of the agents in the team. ${ }^{122}$

A major contribution to the contractual theory of the firm is the classic work by Jensen and Meckling. They characterize the public corporation as a "nexus for a complex set of voluntary contracts among customers, workers,

119. See Id.; Eugene F. Fama \& Michael C. Jensen, Separation of Ownership and Controls, 26 J.L. \& ECON. 301 (1983); Eugene F. Fama \& Michael C. Jensen, Agency Problems and Residual Claims, 26 J. L. \& ECON. 327 (1983); Easterbrook \& Fischel, Corporate Contract, supra note 86; EASTERBROOK \& FISCHEL, ECONOMIC STRUCTURE, supra note 63.

120. See Alchian \& Demsetz, supra note 6.

121. See Bengt Holmström, Moral Hazard in Teams, 13 BeLl J. OF ECON. 324 (1982). Holmström states that "The primary role of the principal is to administer incentive schemes that police agents in a credible way rather than to monitor agents as in Alchian and Demsetz' story." Id. at 328.

122. The firm's ability to use such incentive mechanisms is limited by its ability to make credible commitments, as Innes points out for the standard principal-agent framework. Robert D. Innes, Limited Liability and Incentive Contracting with Ex-ante Action Choices, 52 J. ECON. THEORY 45 (1990). 
managers, and the suppliers of materials, capital, and risk bearing." 123 The economic role of the firms is primarily to manage investments in risky projects. Their analysis provides a fundamental explanation for the establishment and economic success of the corporation. A potential advantage of the firm over direct exchange is that the firm provides a means of separating ownership and control. The firm is a mechanism for allocating control when there is economic risk. Jensen observes that "Corporations, like all organizations, vest control rights in the constituency bearing the residual risk." 124

\section{The Separation Theory of the Firm}

The separation theory of the firm encompasses and builds upon existing theories of the firm. ${ }^{125}$ As in the industrial organization theory, one of the most important activities of the firm is choosing prices. The separation theory of the firm extends the neoclassical separation analysis to price-setting firms and also takes into account the competitive activities of firms that affect market structure and prices. As in the transaction cost theory of the firm, the separation theory of the firm is based on the firm's role in improving the efficiency of transactions. As in the contractual theory of the firm, the separation theory of the firm is concerned with the firm's activities that improve incentives for performance by economic agents.

The separation theory of the firm provides a framework for analyzing the economic role of the firm. The separation criterion distinguishes among transaction institutions and gives a means of formally defining the firm. The definition is based on ownership of the transaction institution and the objectives of the institution and those of its owners. The separation theory of the firm identifies how firms are established by emphasizing the critical functions of the entrepreneur. The separation theory explains how firms are able to improve transaction efficiency in comparison with other types of transaction institutions. By separating its objectives from the consumption objectives of its owners, the firm creates more efficient markets and organizations. The allocation mechanisms offered by firms are the "microstructure" of markets. ${ }^{126}$ Firms provide economic value by intermediating exchange through markets and

123. See Jensen \& Meckling, supra note 6.

124. JENSEN, supra note 6 , at 1 .

125. The separation theory of the firm differs from neoclassical economics in a number of critical areas. The entrepreneur is missing from neoclassical economics but is the central player because the entrepreneur establishes the firm. In neoclassical economics, there are no entrepreneurs because firms already are established. In the separation theory of the firm, the firm is much more than a production technology because the firm is responsible for intermediating transactions. In neoclassical economics, firms take prices as given and make no organizational, management, purchasing, or marketing decisions. Firms do little more than choose the input-output mix that maximizes profits. In neoclassical economics, there are no transaction costs or contracting problems.

126. See SPULBER, supra note 7; SPULBER, supra note 51. 
Discovering the Role of the Firm

organizations.

\section{Markets and the Separation Theory of the Firm}

Chandler identifies large corporations and their managers as the "visible hand" responsible for a large share of economic decision making. ${ }^{27}$ Firms aggregate transactions to create benefits from coordination and scale, thus acting as market makers. They create new types of transactions by bringing buyers and sellers together in innovative ways. Firms centralize markets by intermediating transactions. Without firms acting as intermediaries, markets tend to be decentralized, with individual buyers and sellers handling all communication and computation tasks. Allocations in decentralized markets are characterized by constraints on communication and computation. Costly communication is likely to lead to random search and inefficient matching of buyers and sellers. Costly computation is likely to involve asymmetric information and inefficient allocation mechanisms. Individuals thus encounter network constraints that limit the efficiency of decentralized exchange.

Firms create centralized markets by providing communication and computation services to buyers and sellers. Firms establish and operate information systems that supply buyers and sellers with some of the means to communicate and process information. Firms engage in communication with buyers and sellers to gather information about their characteristics and to provide information about terms of exchange, such as prices and product features. Firms also engage in computation, through their match making and market making activities.

Through centralization of transactions, firms can improve on the efficiency of transactions between consumers. Markets-whether stores, web sites, auction houses, or exchanges-provide central locations where buyers and sellers can meet and transact. Firms reduce search costs by matching buyers and sellers. There are many types of specialized intermediaries and matchmakers that bring buyers and sellers together. Matchmakers operate in markets with homogenous products, introducing buyers and sellers. Matchmaking and brokerage services are of particular importance in markets with differentiated products. Matchmakers take into account buyer and seller characteristics and the features of the products or services to be exchanged. Some types of matchmakers do offer mechanisms for exchange, particularly in the case of online auctions and marketplaces, which provide mechanisms for price adjustment and market clearing.

Brokers are common in financial asset markets, including markets for securities, commodity futures, derivatives, insurance, and loans. Brokers bring

127. CHANDLER, supra note 17. 
buyers and sellers together in return for commissions or fees without taking ownership or directly providing the goods and services being exchanged. Firms gather and disseminate buyer and seller information to improve matches and reduce the costs of search. Pure information providers include: directories such as the Yellow Pages; print and broadcast media that carry advertisements; Internet-based portals with seller or buyer listings; web portals and Internet search engines (Yahoo, Google); publishers of classified advertisements; and media (book publishers, newspapers, journals, terrestrial and satellite broadcasters).

The many types of matchmaking services include the following: residential and commercial real estate brokers; employment and recruiting agencies; staffing and temporary agencies; representative agents (literary, talent, sports); and travel agents and freight transportation brokers. Other types of specialized intermediaries include: dating and marriage matchmakers; interest group matchmakers (Meetup.com); business brokers (for buyers and sellers of businesses); technology and intellectual property brokers; commodity and metals brokers; ship brokers; art brokers; and consignment, and resale stores. Firms intermediate between businesses through various brokerage activities and business-to-business marketplaces.

Firms reduce search costs by aggregating buyer demands and seller supplies. Such aggregation avoids inefficiencies that result from mismatches between individual buyer demands and individual seller supplies. Firms can break up large orders, combine small orders, and match total demand and supply. Large-scale firms also improve market efficiency by bringing together many buyers and sellers, thus reducing reliance on small-scale dealers. By posting prices, market makers provide efficiencies in comparison with a market in which consumers must search across dealers for the best price.

Buyers participate in markets based on their expectations of seller participation and sellers participate in markets based on their expectations of buyer participation. To reduce search costs in financial markets, many types of firms perform market-making functions that bring liquidity to the market. Firms stand ready with funds needed to buy assets if there are not sufficient buyers and they stand ready with financial assets if there are not sufficient sellers. Buyers and sellers can enter the centralized market with confidence that they are unlikely to be rationed due to the absence of a trading partner.

Market makers are dealers that offer to buy and sell financial assets at posted prices. They assure buyers and sellers of liquidity if there are not sufficient counter parties available. Firms that provide liquidity in financial markets include block traders, who are dealers that handle large trades; value traders, who speculate based on superior information about price movements and asset values; and arbitrageurs, who identify differences in the supply and 
demand for liquidity across markets. ${ }^{128}$ In addition, organized exchanges for securities and derivatives provide specialists who act as market makers by quoting bid and ask prices and acting as dealers. Buyers and sellers of financial assets benefit from the liquidity supplied by market makers. Investors can hold assets without being concerned about selling the asset in the future. Other financial firms such as banks and mutual fund companies act as market makers by standing ready to make loans or take deposits or to buy and sell financial assets.

Firms in product markets act as market makers by providing immediacy to their suppliers and customers. ${ }^{129}$ Retailers and wholesalers stand ready to buy from their suppliers. They keep inventories on hand to serve their customers. By aggregating demands and suppliers, specialized firms pool demand-side and supply-side risk. ${ }^{130}$ With market making by firms, consumers need not hold inventories since they can rely on firms to have products on hand when needed. Suppiiers can bring products to market whon it is convenient to provide them, since they can rely on firms to purchase the products. Demsetz notes that in securities markets, "the ask-bid spread is the markup that is paid for predictable immediacy of exchange in organized markets; in other markets it is the inventory markup of retailer and wholesaler." 131

Matching problems arise even without search costs. Consumers face the absence of a double coincidence of wants when they cannot achieve an efficient allocation through bilateral trades. Firms alleviate this problem by serving as an intermediary, thus replacing money as a medium of exchange. Firms also create money by providing various payment systems, including checks and credit cards. The absence of the coincidence of wants can also arise when a buyer and a seller cannot transact with each other at the same time. ${ }^{132}$ The firm addresses such timing issues through market making, standing ready to buy and sell. The absence of a double coincidence of wants can occur when trading partners are in different locations. Firms can solve this problem by intermediating between consumers in different locations. By operating in multiple locations, the firm also reduces the costs of communication and search for consumers who deal with the local branch of the firm. Consumers encounter the absence of a double coincidence of wants when they cannot trade in different states of the world. By creating financial assets, firms allow consumers to carry out exchange under

128. See LARry Harris, Trading and Exchanges: MARKET Microstructure for Practitioners (Oxford Univ. Press 2003), for a practical guide to these financial firms. These definitions are adapted from the institutional discussion in Harris.

129. See Robert Clower \& Axel Leijonhufvud, The Coordination of Economic Activities: $A$ Keynesian Perspective, 65 AM. ECON. REv. 182 (1975).

130. See Chin Lim, Risk Pooling and Intermediate Trading Agents, 14 CANADIAN J. OF ECON. 261 (1981); Daniel F. Spulber, Risk Sharing and Inventories, 6 J. ECON. BEHAVIOR AND ORG. 55 (1985).

131. See Harold Demsetz, The Cost of Contracting, 87 Q. J. ECON. 33 (1968).

132. See also Clower \& Leijonhufvud, supra note 129. 
uncertainty and transfer resources across uncertain states. Coase points out that " $[\mathrm{t}]$ he costs of negotiating and concluding a separate contract for each exchange transaction which takes place on a market must also be taken into account." 133 Coase observes that in certain markets, techniques are devised for minimizing but not eliminating these costs, such as exchanges for fresh produce. Firms have an arsenal of mechanisms for improving the efficiency of transactions relative to decentralized bargaining between individuals. These transaction mechanisms might not be feasible for consumers. Firms offer standardized contracts and other routine business processes that reduce bargaining costs. Firms standardize business processes and achieve economies of scale in transactions. By centralizing exchange, firms can post prices, operate auctions, and standardize exchange.

The firm's posted prices or its auction mechanisms perform a critical separation between buyer demands and seller supplies. With posted prices, the firm trades with buyers who have a willingness to pay above the firm's ask price and the firm trades with sellers who have a cost below the firm's bid price. With double auctions, the firm identifies high-willingness-to-pay buyers and low-cost sellers and separates demands and supplies through the equilibrium prices chosen by the auction.

Firms consolidate the demands of many customers or the supplies of many sellers. The firm then can post prices on the basis of aggregate information about the demand of its customers or the supply offered by its sellers. Alternatively, the firm can gather more detailed information about demand and supply through auction mechanisms or through repeated observation purchases and sales.

There are advantages to posted prices in comparison with bilateral negotiation. Posted prices are convenient for buyers or sellers relative to the time and effort required in negotiating exchange. Transacting at posted prices also removes the uncertainty that may be present in bilateral exchange if consumers have imperfect information about trading partners and thus do not know the outcome of bargaining. Transacting at posted prices improves the value of transactions relative to random matching of buyers and sellers. By adjusting prices to maximize profits, firms balance supply and demand, thus establishing market clearing prices. Firms design markets and allocation mechanisms to overcome the effects of imperfect information.

Net gains from trade in an economy with firms can be increasing in the number of consumers if the firm obtains economies of scale in transactions. Such scale economies can be due to fixed costs of communication and information processing. There may also be benefits from dealing with many consumers if the firm aggregates information. The firm also benefits from

133. Coase, 1937, supra note 6. 
dealing with many consumers if it can pool risks. Finally, the firm increases efficiency by dealing with many consumers if doing so improves the effectiveness of market making. When there are many buyers and sellers, market makers benefit from increased liquidity.

Firms are intermediaries that coordinate buyers and sellers. ${ }^{134}$ Buyers and sellers transact with a firm rather than engaging in direct exchange if the firm increases the benefits minus the costs of the transaction. In practice, firms incur many of the costs of buying and selling, including searching for trading partners, establishing prices, communicating price and product information, negotiating and writing contracts, arranging payments, recording exchange data, and monitoring contractual performance. Firms can reduce the costs of transactions by internalizing some parts of the exchange. Wholesalers and retailers are specialized firms that focus on distribution and sales.

\section{Organizations and the Separation Theory of the Firm}

Firms establish organizations as a means of implementing market transactions and as a way of managing organizational transactions. Firms can improve the efficiency of transactions by substituting transactions within an organization for arms-length transactions, as Coase emphasized. ${ }^{135}$ Firms can be complex organizations with many members and many trading partners. They allocate resources within their organizations, including labor services, capital financing, parts and components, and intellectual property. Firms coordinate the activities of their employees through many types of management procedures and organizational relationships.

Within the organization, firms have extensive communication systems, including the hierarchical chain of command, internal networks of relationships, and information technology networks. The collective efforts of members of the organization overcome some of the limits on the cognition of individuals. Individuals working together in an organization can presumably collect and analyze greater amounts of information than individuals working separately. These affect the ability of individuals to make complex decisions. Of course, there are well known limits on the abilities of organizations as well, such as organizational conflict and bureaucratic inertia.

Herbert Simon examines the implications of limited cognition for organizations. ${ }^{136}$ The organization must deal with limits on an individual's

134. See SPULBER, supra note 7.

135. Coase, 1937, supra note 6.

136. See Herbert A. Simon, Administrative Behavior (Free Press 3d ed. 1976) (1945) (hereinafter "SimON, 1945"); Herbert A. Simon, A Behavioral Model of Rational Choice, 69 Q. J. ECON. 99 (1955); Herbert A. Simon, Theories of Bounded Rationality, in DECISIONS AND ORGANIZATIONS 161 76 (C.B. McGuire \& Roy Radner eds., North Holland 1972). 
ability of perform tasks and make decisions. ${ }^{137}$ The bounded rationality of managers and subordinates results in the need to delegate authority and share information within the organization. ${ }^{138}$ The decisions of managers and employees may involve "satisficing", rather than optimizing, which must be addressed by the design of incentives for individual performance. Because of limits on the knowledge, computation, and decision-making capacity of individuals, the organization breaks large tasks into smaller ones, achieving organizational goals by assigning sub-goals to units of the organization. ${ }^{139}$ March and Simon conclude that organizations engage in adaptive behavior to deal with complex decision making. ${ }^{140}$ Cyert and March present a behavioral theory of the firm that is based on a systems view of strategy-making. ${ }^{141}$ They describe decision making by firms as a process of goal setting, feedback, adaptation, and search. ${ }^{142}$ By combining the forces of many decision makers and taking advantage of specialization and division of labor, organizations can potentially improve information processing and the accuracy of decision making. Knight finds that assignment of individuals to managerial positions may reflect greater capacity for decision-making and information processing. ${ }^{143}$ Stinchcombe suggests that the "social structure of organizations can be explained by the structure of the information problem [with which] they are confronted." 144 Arrow argues that since information is costly, it is more efficient to transmit the information centrally through the upper levels of the hierarchy. ${ }^{145}$ The bounded rationality of economic actors and costly interaction within the organization in turn create bureaucratic inertia and impose limits on the performance of organization in handling uncertainty.

Limits on the information processing ability of individuals constrain their ability to form productive teams. Organizations develop mechanisms to reduce the resulting inefficiencies that yield transaction benefits that might not be achieved through market transactions between team members. The costs of communication channels are highlighted by Marschak and Radner's classic model of communication in teams in which each member of a team imperfectly

137. See SiMON, 1945, supra note 136 , at 39.

138. However, Simon cautions that there are limits to rationality that affect the functioning of the organization: incomplete knowledge, imperfect anticipation of future events, and difficulty in identifying all possible alternatives. SIMON, 1945, supra note 136, at 81-84.

139. JAMES G. MARCH \& HerBert A. SIMON, ORGANIZATIONS 168 (Wiley 1958).

140. See id.

141. See Richard M. Cyert \& James G. MARCH, A Behavioral Theory OF THE Firm (Herbert A. Simon ed., Prentice Hall 1963).

142. Williamson observes that organizations may facilitate "adaptive, sequential decision making, thereby to economize on bounded rationality." WILLIAMSON, MARKETS AND HIERARCHIES, supra note 6 , at 40 .

143. KNIGHT, supra note 6.

144. See ARthur L. StinchCombe, Information and Organizations 29 (University of California Press 1990).

145. See Kenneth J. Arrow, The Limits of Organization (Norton \& Co. 1974) at 68. 
observes the current state of the world at some cost, with the decisions of the team depending on what (costly) channels of communication are established. ${ }^{146}$ In their framework, an organizer is faced with the problem of designing an organizational network that yields the highest expected payoff "net of the costs of observation, communication and computation" incurred by members of the team. ${ }^{147}$ They further point out that the activities of the organizer also are likely to entail similar costs of decision making, as well as costs of resolving conflicts and allocating tasks.

Because firms provide professional management and unity of purpose, they improve performance in comparison with basic partnerships and cooperatives that are subject to group decision making. Operating an organization as a collective agreement can be difficult and inefficient when transaction costs are present due to the complexities and inefficiencies of collective decision making. The costs of communication, negotiating, and monitoring create problems of collective decision making. Firms provide a hierarchical structure in which managers assign tasks, design incentives, and monitor the performance of subordinates. Firms offer efficiencies in comparison to consumer organizations by improving governance.

Many large-scale vertically integrated manufacturing companies developed in the early part of the twentieth century. According to Alfred D. Chandler, there was extensive vertical integration in American business between 1900 and $1917 .{ }^{148}$ The vertical integration of the early twentieth century gave way to vertical disintegration through outsourcing and specialized intermediaries. Many manufacturers are now primarily engaged in design, assembly, and outsource the manufacturing of parts and components. The reduction of vertical integration accompanied a greater focus on the efficiency of market transactions. The role of firms in creating and coordinating transactions is particularly apparent in the retail, wholesale and financial sectors. Firms in these sectors account for approximately a quarter of gross domestic product in the United States. ${ }^{149}$ Retailers are intermediaries between final consumers and wholesalers and manufacturers. Two-thirds of wholesale transactions are sales made by wholesale merchants (including also distributors, jobbers, drop shippers, import/export merchants, grain elevators and farm product assemblers), and agents (including also brokers, commission merchants, import/export agents and brokers, auction companies, and manufacturers'

146. See Jacob Marschak \& Roy Radner, Economic Theory of Teams (Yale Univ. Press 1972).

147. See id. at 313.

148. See CHANDLER, supra note 17 , at 34 (1996).

149. See Daniel F. Spulber, Market Microstructure and Intermediation, 10 J. ECON. PERSP. 135 
agents). ${ }^{150}$ The remaining third of wholesale transactions are sales conducted through manufacturers' sales branches and offices to wholesalers, retailers and other manufacturers. ${ }^{151}$ Financial firms, including banks, securities brokerages, mutual funds, and insurance companies also primarily create transactions. Others that engage in intermediation activities include attorneys, sales agents, real estate brokers, and other specialized agents. All types of companies, including manufacturing firms, spend substantial resources on transactions through their marketing, sales, input purchasing, financing, and other market functions. Transaction activities are an essential part of the establishment and operation of firms.

These developments coincided with reductions in the costs of both market transactions and organizational transactions as a result of technological developments in information processing, communications, and transportation. Lower transaction costs may have reduced the impetus for vertical integration and helped establish new forms of economic exchange. The functions and tasks of management changed but by no means reduced the need for firms. Rather, these economic developments highlighted the economic role firms in managing both market transactions and organizational transactions.

\section{CONCLUSION}

This article presents a general theory of the firm based on the separation criterion. The separation theory of the firm extends Fisher's separation ideas to general economic environments that address imperfect competition, transaction costs, contracts, market microstructure, and organizational design. The firm is a transaction institution whose objectives differ from those of its owners. The general theory of the firm provides a unified framework for studying firms, markets, and organizations. The firm is an intermediary that efficiently combines market mechanisms and organizational mechanisms. The scope of the firm is the full range of its market transactions and organizational transactions. The economic equilibrium involves the endogenous choice of consumers to become entrepreneurs. This leads to the endogenous establishment of firms. By creating and managing markets and organizations, firms help to determine the equilibrium prices and allocation of resources in the economy.

Coordination of transactions is central to the theory of the firm. Entrepreneurs establish firms and transact through firms when doing so enhances the benefits of transactions net of the costs of transactions. Firms create value by making possible transaction efficiencies that consumers could

150. U.S. Census Bureau, United States Census 20001 (2000), available at http://www.census.gov/prod/2002pubs/c2kprof00-us.pdf.

151. Id. 
not realize through direct exchange and consumer organizations. The separation criterion distinguishes firms from other economic institutions such as clubs, cooperatives, and decentralized exchange. The transactions that are observed in an economic equilibrium will involve some combination of direct exchange between consumers and intermediated exchange through firms.

The separation theory of the firm provides insights into corporate law that complement the contractual perspective. The theory places emphasis on the objectives of the institution, the objectives of the owners of the institution, and the benefits of delegation to management. The separation theory of the firm emphasizes the critical importance of shareholders' property rights. The separation theory of the firm highlights transaction benefits from general rules of corporate governance, particularly the separation of the firm's objectives from the consumption objectives of its shareholders. Corporate law must therefore recognize property rights and corporate governance in addition to contractual relationships.

The separation theory of the firm provides public policy insights by identifying how private ownership of firms yields economic benefits. Government regulations that constrain the exercise of property rights by investors fundamentally diminish the effectiveness of the corporation. The firm's capacity to improve the efficiency of transactions derives in large part from its ability to separate the objectives the institution from the consumption objectives of its owners. Rules and regulations intended to address problems of corporate governance can generate perverse incentives by constraining the exercise of shareholder property rights. This suggests the need to review laws and regulations on corporate governance in light of their effects on shareholder property rights. Additionally, those enterprises that are owned and controlled by government are not firms because of the absence of separation of objectives and therefore such enterprises cannot be expected to operate efficiently. Beyond the well-understood benefits of competitive markets, this provides additional reasons to privatize such enterprises and avoid nationalization and takeovers of firms. By discovering the role of the firm in creating markets and organizations, the separation theory of the firm provides important guidance for understanding corporate law. 
